\section{ROLE OF CANNABINOIDS IN ALCOHOL-INDUCED} NEUROINFLAMMATION

Alba García-Baos ${ }^{1+}$, Laia Alegre-Zurano ${ }^{1+}$, Lídia Cantacorps ${ }^{1}$, Ana Martín-Sánchez ${ }^{1,2}$, Olga Valverde ${ }^{1,2^{*}}$.

${ }^{1}$.Neurobiology of Behaviour Research Group (GReNeC-NeuroBio), Department of Experimental and Health Sciences, Universitat Pompeu Fabra, Barcelona, Spain

${ }^{2}$.Neuroscience Research Programme, IMIM-Hospital del Mar Research Institute, Barcelona, Spain.

${ }^{+}$Equally contributed

*Author for correspondence:

Olga Valverde, MD PhD

Neurobiology of Behaviour Research Group (GReNeC - NeuroBio),

Department of Experimental and Health Sciences, Universitat Pompeu Fabra

Dr. Aiguader 88; Barcelona 08003

olga.valverde@upf.edu

Keywords: alcohol, cannabinoids, neuroinflammation, 
AEA

AP-1

$\mathrm{BBB}$

BDNF

cAMP

CB1

CB2

CBD

CBDA

CBG

CBGV

CNS

COX-2

DAGL

DAMPs

eCB

ECS

ERK

FAAH

GFAP

GPCR

HMGB 1

HPC

Iba1

IL

INF- $\gamma$

iNOS

$\mathrm{I} \kappa \mathrm{B} \alpha$

LPS

MAGL

MCP-1

$\mathrm{MCSF}$

MD2

MHCII

MIP-1 $\alpha$

miRNA

MRF-1

MyD88

NAPE-PDL

$\mathrm{Nrf} 2$

$\mathrm{NF}-\kappa \mathrm{B}$

OEA
$\mathrm{N}$-arachidonoylethanolamine or anandamide

Activator protein 1

Blood-brain barrier

Brain-derived neurotrophic factor

Cyclic adenosine monophosphate

Cannabinoid receptor 1

Cannabinoid receptor 2

Cannabidiol

Cannabidiolic acid

Cannabigerol

Cannabigivarin

Central nervous system

Cyclooxigenase-2

Diacylglycerol lipase

Danger associated molecular patterns

Endocannabinoid

Endocannabinoid system

Extracellular signal-regulated kinase

Fatty acid amide hydrolase

Glial fibrillary acidic protein

$\mathrm{G}$ protein-coupled receptor

High mobility group box 1

Hippocampus

Ionized calcium binding adaptor molecule 1

Interleukin

Interferon gamma

Inducible nitric oxide synthase

Inhibitory kappa $\mathrm{B} \alpha$

Lipopolysaccharide

Monoacylglycerol lipase

Monocyte chemoattractant protein 1

Macrophage colony-stimulating factor

Myeloid differentiation protein-2

Major histocompatibility complex II

Macrophage inflammatory protein $1 \alpha$

MicroRNA

Microglia response factor 1

Myeloid differentiation factor 88

$\mathrm{N}$-acylphosphatidylethanolamine-specific phospholipase d-like hydrolase

Nuclear factor erythroid 2-related factor 2

Nuclear factor-kappa B

Oleoylethanolamide 
PFC Prefrontal cortex

PKA

Protein kinase A

PPAR

Proliferator-activated receptor

ROS

Reactive oxygen species

RXR- $\gamma$

Retinoid X receptor- $\gamma$

SDF- $1 \alpha / C X C L 1$

Chemokine stromal cell-derived factor 1

SOC

Suppressors of cytokine signalling

TAK1

Transforming growth factor beta-activated kinase 1

TFG

Transforming growth factor

THC

Tetrahydrocannabinol

THCA

Tetrahydrocannabinolic acid

THCV

Tetrahydrocannabivarin

TLR4

Toll-like receptor 4

TNF- $\alpha$

Tumour necrosis factor alpha

TrkB

Tropomyosin receptor kinase B

TRPV

Transient receptor potential vanilloid type 
- Alcohol exposure leads to a chronic pro-inflammatory profile in the CNS.

- The expanded endocannabinoid system is a key regulator of the neuroimmune response.

- $\mathrm{CB} 1$ activation is related to deterioration of alcohol-induced neuroinflammation.

- Cannabinoids modulate the pro-inflammatory and the anti-inflammatory signalling pathways.

- Targeting the PPAR $\gamma$ or the usage of OEA leads to promising outcomes.

\section{Abstract}

Alcohol is a psychoactive substance highly used worldwide, whose harmful use might cause a broad range of mental and behavioural disorders. Underlying brain impact, the neuroinflammatory response induced by alcohol is recognised as a key contributing factor in the progression of other neuropathological processes, such as neurodegeneration.

43 These sequels are determined by multiple factors, including age of exposure. Strikingly, 44 it seems that the endocannabinoid system modulation could regulate the alcohol-induced neuroinflammation. Although direct CB1 activation can worsen alcohol consequences, 46 targeting other components of the expanded endocannabinoid system may counterbalance 47 the pro-inflammatory response. Indeed, specific modulations of the expanded endocannabinoid system have been proved to exert anti-inflammatory effects, primarily through the CB2 and PPAR $\gamma$ signalling. Among them, some endo- and exogeneous cannabinoids can block certain pro-inflammatory mediators, such as NF- $\kappa \mathrm{B}$, thereby neutralizing the neuroinflammatory intracellular cascades. Furthermore, a number of cannabinoids are able to activate complementary anti-inflammatory pathways, which are necessary for the transition from chronically overactivated microglia to a regenerative microglial phenotype. Thus, cannabinoid modulation provides cooperative antiinflammatory mechanisms that may be advantageous to resolve a pathological neuroinflammation in an alcohol-dependent context. 


\section{Introduction}

58 Alcohol is one of the most consumed psychoactive drugs worldwide, with 2.3 billion ocurrent drinkers. Indeed, alcohol use is among the leading causes of global disease burden (Rehm and Shield, 2019). Around 3 million deaths per year occur due to the harmful use of alcohol, which represents $5.3 \%$ of total deaths (World Health Organization, 2018). Alcohol abuse affects most body organs, although severe alcoholinduced diseases are most notable in the liver, pancreas and brain. This is due to alcohol's direct neurotoxic effect on neurons through different mechanisms, including oxidative stress (Qin and Crews, 2012) and neuroinflammation (Crews and Vetreno, 2014).

Even though alcohol exposure may have a different impact in the central nervous system (CNS) determined by several factors, such as the developmental period of exposure, route of administration or pattern of consumption, there might be a common neuroinflammatory mechanism underlying such alterations. The endocannabinoid system (ECS) has been observed to play a key role in the modulation of neuroinflammatory responses (Chiurchiù et al., 2015; Cristino et al., 2020). In this context, we review and discuss the role of cannabinoids in the regulation of alcohol-induced neuroinflammation.

In this review, we first outline the mechanisms by which alcohol exposure induces a neuroinflammatory response. We also provide an overview on the ECS and its role in regards with the regulation of neuroinflammation. Then, we discuss the molecular mechanisms by which endocannabinoids, phytocannabinoids and synthetic cannabinoids may regulate alcohol-induced neuroinflammatory responses. Additionally, we are interested in alcohol impact on different neurobehavioral outcomes focused on preclinical studies, using cannabinoid-based approaches to modulate the alcohol-induced brain damage (i.e. neuroinflammation, oxidative damage or neurodegeneration) in two different developmental stages: adolescence and adulthood. Finally, we propose a mechanism by which cannabinoid-based therapies could modulate alcohol-induced neuroinflammatory signalling.

\section{Alcohol-induced neuroinflammatory response.}

The immune response within the CNS involves peripheral and local elements, primarily microglia and astrocytes, together forming the so-called glia (Gilhus and Deuschl, 2019). 
87 Both cell types are highly reactive to changes in the brain, actively producing signalling

114 In accordance with clinical data, some preclinical studies have displayed an increase of 115 pro-inflammatory markers after alcohol exposure even though several factors can 116 influence the alcohol's effect on neuroimmune activation. Vallés and colleagues 
117 demonstrated an enhanced expression of inducible nitric oxide synthase (iNOS),

118 cyclooxigenase-2 (COX-2) and IL-1 $\beta$, within the cerebral cortex of female Wistar rats,

119 following a 5-months chronic alcohol treatment (Vallés et al., 2004). 10-days of alcohol

120 treatment (5 g/kg; i.g.) increased brain TNF- $\alpha$ and MCP-1 levels, whereas it reduced IL-

121 10, which is an anti-inflammatory cytokine, in adult male C57BL/6 mice (Qin et al., 122 2008).

123 Other authors have suggested an age- and region-specific susceptibility to alcohol 124 regulation of neuroinflammatory response (Kane et al., 2014; Pascual et al., 2007; Perkins 125 et al., 2019). Although divergences could also be due to the usage of different models of 126 alcohol exposure, highlighting the importance of dose, route of administration and timing 127 of exposure in the alcohol-induced neuroinflammatory response. Nevertheless, aging128 associated changes in neuroimmune response are known to play a key role in adolescent 129 versus adult alcohol-induced neuroinflammation, which are to take into account (Perkins 130 et al., 2019). Hence, the period of lifetime in which alcohol exposure occurs is important 131 in terms of the severity of neuroinflammatory response and the following negative 132 consequences.

133 Sex factor seems to be relevant as well. When male and female mice were compared, 134 iNOS, COX-2, IL-1 $\beta$ and TNF- $\alpha$ were increased in cerebral cortex of both sexes. 135 However, alcohol induced higher glial fibrillary acidic protein (GFAP) levels in females 136 versus males (Alfonso-Loeches et al., 2013). On the other hand, concerning the 137 methodology, the time point examining post-exposure, the techniques to analyse the 138 protein and mRNA content, and the species used can also influence the changes on 139 immune signature (see (Melbourne et al., 2019) for more information).

140 Thus, the interaction between alcohol and neuroimmune system is complex and still

141 remains unclear. Although the number of studies focused on this field has been increasing

142 in the last decades, reports are not particularly consistent because of the influence of many 143 external factors.

\subsubsection{Central mechanisms}


146 Taken together, it seems that alcohol exposure can be defined as an insult that leads to 147 neuroimmune dysregulation in some situations. These neuroimmune alterations are 148 mostly mediated by central mechanisms that lead to the activation of microglia, which 149 can persist for long periods once activated by excessive alcohol consumption (Liu et al., 150 2008; Vetreno et al., 2013). Alcohol molecule can cross the blood-brain barrier (BBB) to 151 induce a local pro-inflammatory response due to the activation of Toll-like receptors 152 (TLRs) in glial cells (Coleman and Crews, 2018; Crews and Vetreno, 2016). In addition, 153 alcohol exposure may induce the release of endogenous danger associated molecular patterns (DAMPs), such as the high mobility group box 1 (HMGB1), by neurons and glia during glutamate hyperexcitation (Maroso et al., 2011; Zou and Crews, 2005) or by necrotic dead cells (Crews and Vetreno, 2016). DAMPs in extracellular space activate TLRs and other pro-inflammatory-associated receptors, such as the receptor for advanced glycation end products (Park et al., 2004). The activation of these receptors induces the stimulation of pro-inflammatory signalling pathways and activation of transcriptional factors, such as nuclear factor kappa B (NF- $\mathrm{B}$ ) and activator protein 1 (AP-1), through the myeloid differentiation factor 88 (Myd88)-dependent pathway. Furthermore, a hyperactivation of pro-inflammatory oxidases occurs when alcohol is metabolized, resulting in the formation of reactive oxygen species (ROS). Altogether cause positive loops of pro-inflammatory responses in the brain that converge upon NF- $\kappa \mathrm{B}$ activation and its subsequent translocation into the nucleus, which will keep on amplifying the neuroimmune gene induction through autocrine and paracrine positive feedbacks (Crews and Vetreno, 2016).

During such periods of activation, microglia suffers morphological and functional changes. Thus, authors suggested that a single period of binge alcohol drinking does not induce a full microglial-driven neuroinflammatory response, but a partial microglial activation that persists until adulthood (McClain et al., 2011). In a chronic but moderate alcohol exposure model using a vapor chamber for 5 weeks, increased number of Iba1-

173 positive cells were observed at the first day of withdrawal in many brain regions, including frontal cortex, HPC, amygdala, substantia nigra and cerebellum. Furthermore,

175 Iba1 staining remained elevated after 28 days of withdrawal in amygdala, frontal cortex 176 and substantia nigra (Sanchez-Alavez et al., 2019). Accordingly, a chronic alcohol 177 drinking model over 6 months induced long-lasting partial microglial activation in rat 178 HPC (Cruz et al., 2017). On the other hand, other authors have shown an increased 
number of MHCII-, CD45- and CD68-positive cells in a chronic alcohol-drinking model

180 over 5 months in mice, suggesting an activated ameboid phenotype in this case. Elevated levels of pro-inflammatory cytokines and chemokines, including chemokine ligand 2 and fractalkine, were reported in this study following a chronic alcohol exposure (AlfonsoLoeches et al., 2016).

Therefore, one may confirm that there is no clear consensus about the activated microglial phenotype induced by alcohol and its functional implications. Again, there are several factors that might lead to a different neuroinflammatory response. Interestingly, evidence suggests a possible association between chronic or excessive alcohol consumption with pro-inflammatory microglial phenotypes, whereas single or moderate drinking episodes could be accompanied by homeostatic responses. However, further studies should be addressed to clarify the influence of the factors mentioned upon the microglial phenotype, alongside the role of this microglial activation following alcohol exposure. Thus, whether this neuroimmune activation is detrimental or neuroprotective remains a subject of debate.

However, some studies in attempt to assess causality have exhibited that the deletion of TLR4 prevents the neurotoxicity through the blockade of alcohol-induced activation of microglia (Erickson et al., 2019). TLR4 deletion prevented alcohol-induced upregulation of CD11b (microglial marker) and GFAP immunoreactivity. Furthermore, in this

198 knockout mouse model the increase of caspase-3 and iNOS activity, as well as the increase of COX-2, IL-1 $\beta$, TNF- $\alpha$ and IL- 6 in the cerebral cortex of female mice, were also prevented following a 5-month chronic alcohol treatment (Alfonso-Loeches et al., 2010). Another study has shown that the inflammatory response induced by alcohol treatment was completely abolished in microglia of TLR4-deficient mice (FernandezLizarbe et al., 2009). Altogether, it is relatively clear that the activation of microglia under certain alcohol exposure conditions could be somehow detrimental for the CNS, supporting the hypothesis of neuroimmune activation in the pathophysiology of AUDs.

206 Noteworthy, microglia may as well promote repair under many homeostatic and

207 pathological conditions, including other certain types of alcohol exposure mentioned 208 above. 
210 The presence of alcohol increases blood's innate immune signals released from peripheral

211 organs. The gut and liver are especially affected by alcohol intake as it has been reported

212 in different studies; therefore, pro-inflammatory markers can be released when they are

213 dramatically affected by alcohol exposure (de Timary et al., 2017; Ferrier et al., 2006;

214 Gao et al., 2011). Alcohol increases the intestinal permeability (Antón et al., 2018),

215 allowing the release of pathogen-associated molecular patterns into the bloodstream, such

216 as LPS endotoxin, stimulating pro-inflammatory cytokine production. These circulating

217 immune signals, primarily cytokines and chemokines (i.e.:TNF- $\alpha$, IL-6, IL-1 $\beta$ and

218 chemokine stromal cell-derived factor 1 (SDF-1 $\alpha / \mathrm{CXCL} 1)$ ), are proposed to contribute

219 to neuroimmune activation in AUD as various immune-to-brain communication

220 pathways have been described (Banks and Erickson, 2010; Crews et al., 2006; de Timary

221 et al., 2017). First, circulating pro-inflammatory cytokines may activate the

222 hypothalamus-pituitary-adrenal axis through the vagus nerve stimulation (so-called

223 'neural pathway'). Moreover, peripheral signals can reach the brain via circumventricular

224 organs, meninges and the choroid plexus, structures with a 'leaky' BBB, and they can

225 also act on brain endothelium to induce the release of secondary mediators eliciting a

226 response into the brain (named 'humoral pathway). In addition, endothelial cells may

227 become activated by circulating cytokines and secrete inflammatory mediators that alter

228 the permeability of the BBB, allowing the recruitment of peripheral immune cells (known

229 as 'cellular pathway') (Capuron and Miller, 2011; D’Mello and Swain, 2017; Dantzer et

230 al., 2008).

\section{Cannabinoids and neuroinflammation}

\subsection{The endocannabinoid system}

233 The search for specific binding sites for tetrahydrocannabinol (THC) lead to the first

234 identification of cannabinoid receptor 1 (CB1) (Devane et al., 1988) and cannabinoid 235 receptor 2 (CB2) (Matsuda et al., 1990; Munro et al., 1993). CB1 is considered to be the 236 most abundant G-protein coupled receptor (GPCR) within the CNS (Irving et al., 2008)

237 being primarily expressed in axon terminals (Freund et al., 2003). When activated, CB1 238 inhibits neurotransmitter release from both presynaptic glutamatergic (Katona et al., 239 2006) and GABAergic neurons (Katona et al., 1999). CB2 is found in lower levels in the 240 brain, being mostly located in microglia (Atwood and Mackie, 2010; Walter et al., 2003). 
241 The spread localization among immune cells confers CB2 a key role in the modulation of 242 inflammatory processes.

243 The most studied endogenous ligands to CB1 and CB2 are N-arachidonoylethanolamine 244 or anandamide (AEA) and 2-arachidonoylglycerol (2-AG) (Lu and MacKie, 2016). 245 Endocannabinoids (eCB) are synthesized on demand and, unlike classic 246 neurotransmitters, are not stored into vesicles, but immediately released from 247 postsynaptic cells (Di Marzo et al., 1998). The main enzymes involved in the synthesis 248 of eCB are N-acylphosphatidylethanolamine-specific phospholipase d-like hydrolase 249 (NAPE-PLD) (Okamoto et al., 2004) and diacylglycerol lipase (DAGL) $\alpha$ and $\beta$ (Bisogno 250 et al., 2003), for AEA and 2-AG respectively. The canonical metabolic pathway for eCBs 251 degradation is the hydrolysis of AEA by fatty acid amide hydrolase (FAAH) (Cravatt et 252 al., 1996) and 2-AG by monoacylglycerol lipase (MAGL) (Dinh et al., 2002). However, 253 eCBs can also be degraded by oxygenation via cyclooxygenase-2 (COX-2), among others 254 (Di Marzo et al., 2000).

255 These receptors, ligands and enzymes responsible for their synthesis and degradation 256 constitute the ECS, which is a neuromodulatory system engaged in a wide range of 257 physiological roles, such as brain development, homeostasis, neurotransmitter release, 258 synaptic plasticity and immune response (Lu and MacKie, 2016). In order to develop its 259 function, the ECS directly or indirectly interplays with other components of the CNS 260 leading to what some authors have called the expanded endocannabinoid system (Cristino 261 et al., 2020). Therefore, other $\mathrm{N}$-acylethanolamines, such as oleoylethanolamide (OEA), 262 or 2-acylglycerols molecules, as well as long-chain $\mathrm{N}$-acyl-amides can also interact with 263 cannabinoid and cannabinoid-like receptors, such as peroxisome proliferator-activated 264 receptor (PPAR), orphan receptor GPR or transient receptor potential (TRP) channel 265 (Cristino et al., 2020).

\subsection{Cannabinoid signalling in neuroinflammation}

267 The wide distribution of ECS throughout the CNS and the immune system confers 268 cannabinoids a privileged position for the regulation of neuroinflammatory responses. 269 Although CB1 is most expressed in neurons, it can also be found in glial cells in the brain 270 (Stella, 2010). The stimulation of CB1 has been shown to diminish the release of pro271 inflammatory cytokines, iNOS and ROS via NF-אB pathway inhibition (Lou et al., 2016; 
272 Ribeiro et al., 2013) and protect from excitotoxicity (Marsicano, 2003). Besides, some 273 studies have also proved that CB1 antagonists can indirectly induce an anti-inflammatory 274 response (Kaplan, 2013).

275 Due to its microglial localization, CB2 is highly involved in the modulation of 276 neuroimmune responses. CB2 levels in the CNS increase drastically in neurodegenerative 277 disorders (Aymerich et al., 2018; Cassano et al., 2017) or after brain insults (Cabral and 278 Griffin-Thomas, 2009). Nevertheless, the range of the alcohol-induced neuroinflammatory response is probably less profound and so, its effects on central CB2 280 levels might be fewer. Still, CNR2 gene expression is increased in alcohol users and in 281 human monocyte-derived dendritic cells treated with alcohol (Agudelo et al., 2013), 282 although more studies focusing on the alcohol effects on central CB2 levels would be 283 clarifying. In fact, CB2 levels in microglia are phenotype-dependent, being principally 284 expressed in activated and primed microglia (Stella, 2010). The activation of CB2 is 285 related to decreases in pro-inflammatory cytokines (TNF- $\alpha$, interferon gamma (IFN- $\gamma$ ), 286 IL-1, IL-2, IL-6 or IL-12) (Croxford and Yamamura, 2005; Mecha et al., 2016; Yuan et 287 al., 2002), chemokines (Bátkai et al., 2012; Sheng et al., 2005) and iNOS (Wen et al., 288 2015; Zarruk et al., 2012) via inhibition of the NF- $\mathrm{BB}$ pathway (Fakhfouri et al., 2012; 289 Jeon et al., 1996). Hence, CB2 would act as a homeostatic regulator, bringing the system 290 back to physiological states.

291 Cannabinoids also bind to other non-cannabinoid receptors in the so-called expanded 292 cannabinoid system in order to exert its anti-inflammatory and homeostatic functions.

293 eCBs (AEA and other endocannabinoid-like mediators) (Cristino et al., 2020), 294 phytocannabinoids (cannabidiol (CBD), cannabidiolic acid (CBDA), cannabigerol 295 (CBG), tetrahydrocannabinolic acid (THCA)) (Di Marzo, 2018) and synthetic 296 cannabinoids (WIN55,212-2) (Fakhfouri et al., 2012) are agonist of PPARs, which are 297 nuclear receptors that inhibit NF- $\mathrm{KB}$ and AP1-mediated inflammation (Varga et al., 298 2011a). In the CNS, PPARs are expressed in neurons and glial cells (Moreno et al., 2004). 299 Out of its three isoforms, PPAR $\alpha$ and specially PPARy are involved in the regulation of 300 neuroinflammation and lipid metabolism, whereas PPAR $\beta / \delta$ remains the least studied one 301 (Varga et al., 2011a). Interestingly, their activation has been shown to exert protective 302 effects in different alcohol intake models (Alen et al., 2018; Blednov et al., 2015; 303 Cippitelli et al., 2017). 
304 TRP channels are highly related to the eCB signalling. Indeed, TRP vanilloid 1 (TRPV1),

305 TRPV2, TRPV3, TRPV4, TRP ankyrin 1 and TRP melastatin 8 have all been reported to 306 mediate cannabinoid activity (Muller et al., 2018). TRPV1 has recently been shown to 307 control microglial activation and glutamate release from microglial microvesicles 308 (Marrone et al., 2017). Another recent study also found that TRPV1 regulate cytokine 309 release from activated microglia (Bassi et al., 2019). The eCBs AEA and 2-AG (Lowin 310 and Straub, 2015; Petrosino et al., 2016), some phytocannabinoids, such as 311 tetrahydrocannabivarin (THCV), CBD, CBG or cannabigivarin (CBGV) (De Petrocellis 312 et al., 2011), and several synthetic cannabinoids, such as WIN55,212-2 (Soethoudt et al., 313 2017), bind to TRPV1.

314 The orphan receptor GPR55 has also been proposed as an eCB receptor. Some studies 315 have revealed that AEA and 2-AG bind and activate GPR55 (Lauckner et al., 2008; 316 Ryberg et al., 2007), whereas CBD acts as an antagonist (Kaplan et al., 2017) and THC 317 as an agonist (Lauckner et al., 2008). Furthermore, atypical synthetic cannabinoids, other 318 than WIN55,212-2, can also activate this receptor (Johns et al., 2007). GPR55 levels are 319 microglia-activation dependent, mimicking the regulatory pattern of CB2 and conferring 320 a potential role in the regulation of inflammatory responses (Pietr et al., 2009). Other 321 orphan receptors could also play an important role in neuroinflammation: GPR18 due to 322 its microglial localization (McHugh, 2012), or GPR119 due to the binding of OEA, 323 among other cannabinoid-like mediators (Hansen et al., 2012). Nevertheless, little is 324 known about the physiological roles of these receptors as wells as their interactions with 325 the endocannabinoid system and the immune response which are yet to be elucidated.

326 Besides, due to their lipidic nature, eCBs are highly related to the eicosanoid system 327 (Grabner et al., 2017). Prostaglandins, a classical eicosanoid, are arachidonic acid-derived 328 bioactive lipid mediators synthetized by $\mathrm{COX}-1 / 2$ that have a prominent role in the 329 regulation of inflammatory processes (Aoki and Narumiya, 2012; Dennis and Norris, 330 2015). Indeed, prostaglandins are thought to mediate the transition to chronic 331 inflammation via different mechanisms including the amplification of pro-inflammatory 332 cytokines (Chiurchiù et al., 2018). Although phospholipase A2 is considered to be the 333 main source of the prostaglandin precursor arachidonic acid, the hydrolysis of 2-AG by 334 MAGL has also been proved to generate it (Grabner et al., 2017; Long et al., 2009; 335 Schlosburg et al., 2010). In this line, MAGL inhibition might protect from the 
336 prostaglandin-induced neuroinflammation, as evidenced in a mouse model of Parkinson 337 disease (Nomura et al., 2011).

338 The neuroimmune modulatory profile of cannabinoids has led to the emergence of a wide 339 range of studies exploiting these molecules for the treatment of neurological and 340 neurodegenerative diseases. Endogenous, phytogenic and synthetic cannabinoids have 341 been proved to ameliorate neuroinflammation induced by different pathologies, such as 342 Alzheimer's disease (Maroof et al., 2013; Vallée et al., 2017), Parkinson's disease (Kelly 343 et al., 2020; Little et al., 2011), multiple sclerosis (Al-Ghezi et al., 2019; Correa et al., 344 2007), neuropathic pain (Donvito et al., 2018), autism spectrum disorder (Araujo et al., 345 2019) or addiction (Rodrigues et al., 2014).

\section{Cannabinoids in alcohol-induced neuroinflammation}

347 Alcohol exposure may have a different impact on neurobehavioral outcomes depending

348 on the developmental timing of exposure. Subsequently, we divided our discussion about 349 the role of cannabinoids in alcohol-induced neuroinflammation by the developmental 350 period at which alcohol exposure took place.

\subsection{Adolescent alcohol exposure}

352

Adolescence represents a period in which the brain is undergoing extensive maturational processes. Therefore, alcohol consumption during this time can cause structural and functional changes in immature brain areas resulting in cognitive and behavioural deficits (Kyzar et al., 2016). Compelling evidence has shown that the activation of the immune system plays a crucial role in the disruptive effects induced by adolescent alcohol use (Guerri and Pascual, 2019; Lamont et al., 2020; Pascual et al., 2018). Accordingly, Sanchez-Marin et al. (2017) have shown that 4-week intermittent alcohol exposure (3 $\mathrm{g} / \mathrm{kg}$ injections for 4 days/week) during adolescence induces anxiogenic-like responses and impairs recognition memory later in life. Furthermore, these behavioural alterations were associated with changes in the ECS and neuroinflammation-related factors. Increased levels of the enzymes that mediate the synthesis of AEA and 2-AG, NAPEPLD and DAGLs, were found in the medial prefrontal cortex (mPFC) of alcohol-exposed rats. In addition, an up-regulation of pro-inflammatory mediators, such as TLR4, TNF- $\alpha$, COX-2 and GFAP, was induced by alcohol exposure in the mPFC. Notwithstanding, 
366 lower mRNA levels of the receptors CB1 and CB2, as well as, decreased expression of 367 COX-2, GFAP, microglia response factor 1 (MRF-1) and NF- $\kappa$ B were observed in the striatum. Therefore, brain region-dependent changes of the ECS and neuroinflammation were induced by adolescent intoxication in rats.

370 Some modulations of the eCBs have been described to confer neuroprotective effects against the oxidative damage induced by binge alcohol drinking in adolescence. Selective pharmacological inhibition of the FAAH enzyme, which metabolizes the $\mathrm{N}$ acylethanolamines, blocked the induction of oxidative stress resulting from binge alcohol consumption (Pelição et al., 2016). Pre-treatment with a single dose of the FAAH inhibitor URB597 (0.3 mg/kg; i.p.) was able to prevent the production of free radicals after acute ( 3 consecutive sessions) or chronic ( 3 consecutive sessions over 4 weeks) alcohol bingeing ( $6 \mathrm{~g} / \mathrm{kg}$; i.g.) in the PFC of young rats, avoiding the neurotoxicity of alcohol abuse. Similarly, Bellozi et al. (2019) reported the ability of URB597 pretreatment $(0.3 \mathrm{mg} / \mathrm{kg}$; i.p. $)$ to modulate neuroinflammation induced by binge alcohol consumption during adolescence. The blockade of FAAH prevented the increase of IFN$\gamma$ and TNF- $\alpha$ levels in the PFC and HPC induced by chronic alcohol bingeing ( 3 or $6 \mathrm{~g} / \mathrm{kg}$, i.g.; 3 days/week for 4 weeks). Moreover, URB597 reduced the levels of IL-4, IL-10 and BDNF in the PFC. Thus, the amplification of the ECS seems to exert neuroprotective functions against alcohol-induced neuronal damage, albeit the exact underlying mechanism needs to be further clarified. It is known that URB597 increases AEA (also PEA and OEA) availability, which interacts with PPAR family receptors, known for their anti-inflammatory and antioxidant activities.

In this context, the role of OEA, a structural analogue of AEA, has been investigated to counteract the alcohol-induced damage. Using a 5-week pharmacological administration of OEA (10 mg/kg/day; i.p.; 5 days/week) in a rat model of binge-like alcohol consumption ( $3 \mathrm{~g} / \mathrm{kg}$, i.g.; weekly) combined with acute administrations of THC (5 $\mathrm{mg} / \mathrm{kg}$; i.p) during adolescence, Silva-Peña et al. (2019) demonstrated that OEA was capable of preventing the short-term spatial memory impairments induced by alcohol and

394 THC. Furthermore, combined administration of OEA and THC restored the alcoholinduced BDNF deficiency in plasma. However, OEA reduced mRNA expression of

396 BDNF in the HPC, even though it increased the expression of its receptor tropomyosin 397 receptor kinase $\mathrm{B}(\operatorname{TrkB})$. In addition, repeated administration of OEA rescued the 
reduction of neural stem cell proliferation and newborn cell survival in the subgranular zone of the dentate gyrus induced by alcohol and THC exposure and increased the hippocampal levels of phospho-AKT and phospho-ERK1, key signalling regulators of neurogenesis and cell survival. Also, both treatments (THC and OEA) alone or in combination diminished the mRNA levels of the pro-apoptotic protease caspase- 3 in the HPC. Hence, OEA and other putative PPAR- $\alpha$ activators seem to display a protective role in response to cognitive and brain dysfunctions related to alcohol exposure.

Recently, another approach by which memory deficits induced by adolescent alcohol exposure can be rescued through the modulation of the ECS in mice has been described (Peñasco et al., 2020). Repeated binge alcohol drinking (20\% (v/v); 4 days/week for 4 weeks) during adolescence leads to long-term deficits in CB1 receptor expression and distribution in the brain and consequently, it disrupts a form of excitatory long-term depression that is dependent on CB1 receptors (eCB-eLTD) in the hippocampal dentate gyrus. These alterations were associated with an impairment of recognition memory in alcohol-exposed mice 2 weeks after the cessation of alcohol consumption, which could 413 be rescued by inhibiting the MAGL with JZL184 ( $8 \mathrm{mg} / \mathrm{kg})$. Therefore, increasing the 414 availability of the endogenous 2-AG restored the functional deficits induced by adolescent binge alcohol exposure.

416 However, co-exposure of WIN-55,212-2 (3 mg/kg; s.c.) with alcohol (increasing 417 concentrations of alcohol solution; 3-8\% (v/v) alcohol) during early adolescence (PD 21418 30) increased anxiety-like behaviour (PD 35) and enhanced alcohol intake and preference 419 (6\% (v/v) alcohol) in mice (up to PD 75) (Frontera et al., 2018). In addition, WIN-55,2124202 treatment increased the number of dendritic ramifications in neurons of the substantia 421 nigra but lowered the number of dendritic spines in alcohol-exposed mice. These results 422 demonstrated that exposure to a cannabinoid receptor agonist during adolescence could 423 interfere with neural development affecting the neuronal morphology in key brain areas that ultimately lead to functional and behavioural changes.

To summarize, extensive evidence has been focused on the interaction between alcohol and cannabinoids along adolescence (see Table 1). Co-exposure of alcohol and potent

427 CB1 agonist drugs, such as THC or WIN-55,212-2, enhances alcohol-induced brain 428 damage, in addition to accentuating functional deficits regarding behavioural domains 429 like cognition. Interestingly, several studies have already reported the advantage of 
430 implementing other cannabinoid-based approaches. Again, the data discussed above 431 suggests that preventing CB1 activation while acting through other targets, which are part 432 of the expanded endocannabinoid system, such as N-acylethanolamines/PPARs 433 pathways, could be a beneficial strategy to avoid alcohol-induced brain damage in this 434 developmental period. 

neurodegeneration during the adolescence.

\begin{tabular}{|c|c|c|c|c|c|c|c|}
\hline Reference & $\begin{array}{l}\text { Animal } \\
\text { model }\end{array}$ & $\begin{array}{c}\text { Alcohol } \\
\text { administration }\end{array}$ & $\begin{array}{c}\text { Cannabinoid } \\
\text { treatment }\end{array}$ & $\begin{array}{l}\text { EtOH molecular } \\
\text { effects }\end{array}$ & $\begin{array}{c}\text { Cannabinoid molecular } \\
\text { effects }\end{array}$ & Synergic effects & $\begin{array}{c}\text { Behavioural } \\
\text { improvement/ } \\
\text { impairment }\end{array}$ \\
\hline $\begin{array}{l}\text { Bellozi et } \\
\text { al., (2019) }\end{array}$ & $\begin{array}{l}\text { Male Wistar } \\
\text { rats }\end{array}$ & $\begin{array}{l}\text { Acute binge } \\
\text { alcohol ( } 3 \text { or } 6 \\
\text { g/kg; i.g.) for } 3 \\
\text { consecutive days } \\
\text { Chronic binge } \\
3 \text { binge cycles over } \\
4 \text { weeks } \\
\text { (PD30) }\end{array}$ & $\begin{array}{l}\text { URB597 } \\
0.3 \mathrm{mg} / \mathrm{kg} \text {; i.p., } 40 \mathrm{~min} \\
\text { before the alcohol } \\
\text { administration }\end{array}$ & $\begin{array}{l}\text { Chronic binge } \\
\uparrow \text { IFN- } \gamma \text { and TNF- } \alpha \text { in } \\
\text { PFC and HPC. } \\
\uparrow \text { IL-10 and BDNF in } \\
\text { PFC. }\end{array}$ & No effects & $\begin{array}{l}\downarrow \text { IFN- } \gamma \text { and TNF- } \alpha \text { in } \\
\text { PFC and HPC ( } v s . \\
\text { chronic alcohol binge } \\
\text { group). } \\
\downarrow \text { IL- } 4 \text {, IL-10 and BDNF } \\
\text { in PFC ( } v s . \text { chronic } \\
\text { alcohol binge group). }\end{array}$ & $\begin{array}{l}\uparrow \text { long-term memory in } \\
\text { novel object recognition } \\
\text { ( } v s . \text { acute } 3 \mathrm{~g} / \mathrm{kg} \text { alcohol } \\
\text { binge group). }\end{array}$ \\
\hline $\begin{array}{l}\text { Peliçao et } \\
\text { al., (2016) }\end{array}$ & $\begin{array}{l}\text { Male Wistar } \\
\text { rats }\end{array}$ & $\begin{array}{l}\text { Acute binge } \\
\text { alcohol ( } 3 \text { or } 6 \\
\text { g/kg; i.g.) for } 3 \\
\text { consecutive days } \\
\text { Chronic binge } \\
3 \text { binge cycles over } \\
4 \text { weeks } \\
\text { (PD30) }\end{array}$ & $\begin{array}{l}\text { URB597 } \\
0.3 \mathrm{mg} / \mathrm{kg} \text {, i.p., } 40 \mathrm{~min} \\
\text { before the alcohol } \\
\text { administration }\end{array}$ & $\begin{array}{l}\text { Acute }(3 \text { and } 6 \mathrm{~g} / \mathrm{kg}) \\
\text { and chronic }(6 \mathrm{~g} / \mathrm{kg}) \\
\text { binge } \\
\uparrow \text { production of } \\
\text { superoxide anions } \\
\text { (oxidative stress) in } \\
\text { PFC. }\end{array}$ & No effects & $\begin{array}{l}\downarrow \text { oxidative stress in PFC } \\
\text { (vs. acute and chronic } 6 \\
\mathrm{~g} / \mathrm{kg} \text { alcohol binge). }\end{array}$ & Not applicable \\
\hline
\end{tabular}




\begin{tabular}{|c|c|c|c|c|c|c|c|}
\hline $\begin{array}{l}\text { Silva-Peña } \\
\text { et al., } \\
(2019)\end{array}$ & $\begin{array}{l}\text { Male Wistar } \\
\text { rats }\end{array}$ & $\begin{array}{l}\text { EtOH } \\
3 \mathrm{~g} / \mathrm{kg} \text {; i.g. once per } \\
\text { week for } 5 \\
\text { consecutive weeks } \\
\text { (PD34-69) }\end{array}$ & $\begin{array}{l}\text { OEA } \\
10 \mathrm{mg} / \mathrm{kg} \text {; i.p; } 5 \\
\text { days/week, for } 5 \\
\text { weeks } \\
\Delta^{9} \text {-THC } \\
5 \mathrm{mg} / \mathrm{kg} \text {; i.p.; } 1 \\
\text { day/week for } 5 \text { weeks } \\
\text { Combination of both }\end{array}$ & $\begin{array}{l}\uparrow \mathrm{ERK} 1 \text { and ERK2 in } \\
\text { HPC } \\
\downarrow \text { pERK1/ERK1 and } \\
\text { pERK2/ERK2 in HPC }\end{array}$ & Not applicable & $\begin{array}{l}\text { OEA } \\
\uparrow \mathrm{pAKT} / \mathrm{AKT} \text { and } \\
\text { pERK1/ERK1 protein } \\
\text { levels in HPC } \\
\text { THC + OEA } \\
\downarrow \text { Casp-3 mRNA }\end{array}$ & $\begin{array}{l}\text { OEA } \\
\text { blocks the short-term } \\
\text { spatial-memory } \\
\text { impairment (Y-maze) in } \\
\text { rats induced by } \\
\text { THC+alcohol. }\end{array}$ \\
\hline $\begin{array}{l}\text { Frontera et } \\
\text { al., (2018) }\end{array}$ & $\begin{array}{l}\text { Male CD1 } \\
\text { mice }\end{array}$ & $\begin{array}{l}\text { Forced EtOH } \\
\text { consumption } \\
\text { alcohol 3\% (PD21- } \\
\text { 24), alcohol 6\% } \\
\text { (PD25-27), alcohol } \\
8 \%(\mathrm{PD} 28-29) \text {. }\end{array}$ & $\begin{array}{l}\text { WIN55-212,2 } \\
\text { 3mg/kg, s.c. daily } \\
\text { administered } \\
\text { (P30-P35) }\end{array}$ & Not applicable. & Not applicable. & $\begin{array}{l}\uparrow \text { dendritic ramifications } \\
\text { in neurons of the } \\
\text { substantia nigra } \\
\downarrow \text { number of dendritic } \\
\text { spines }\end{array}$ & $\begin{array}{l}\uparrow \text { alcohol preference } \\
\text { (two-bottle choice). } \\
\uparrow \text { anxiety-like behaviour } \\
\text { in the open field. }\end{array}$ \\
\hline $\begin{array}{l}\text { Peñasco et } \\
\text { al., (2020) }\end{array}$ & $\begin{array}{l}\text { Male } \\
\text { C57BL/6 } \\
\text { mice }\end{array}$ & $\begin{array}{l}\text { DID test } \\
\text { Limited access to } \\
20 \% \text { (v/v) alcohol } \\
\text { for } 4 \text { days/week } \\
\text { over } 4 \text { weeks } \\
\text { (PD32-56) }\end{array}$ & $\begin{array}{l}\text { JZL184 } \\
8 \text { mg/kg, i.p. } \\
\text { (PD 67-71) }\end{array}$ & $\begin{array}{l}\downarrow \mathrm{CB} 1 \text { receptor- } \\
\text { mediated excitatory } \\
\text { transmission } \\
\downarrow \text { eCB-eLTD at medial } \\
\text { perforant path } \\
\text { synapses. }\end{array}$ & Not applicable. & $\uparrow$ eCB-eLTD & $\begin{array}{l}\text { JZL184 rescued alcohol- } \\
\text { induced deficits in } \\
\text { recognition memory }\end{array}$ \\
\hline
\end{tabular}


Alcohol molecular effects (alcohol group vs vehicle control group); Cannabinoid molecular effects (cannabinoid group vs vehicle control group); Synergic effect (alcohol + cannabinoid group vs alcohol group). Abbreviations: $\Delta$ 9-Tetrahydrocannabinol ( $\Delta 9$-THC); Brain-derived neurotrophic factor (BDNF); Hippocampus (HPC); Interferon- $\gamma$ (IFN- $\gamma$ ); Interleukin (IL); intragastrical (i.g.); intraperitoneal (i.p.); Oleoylethanolamide (OEA); Postnatal day (PD); Prefrontal cortex (PFC); subcutaneous (s.c.); Tumour 441 necrosis factor- $\alpha(\mathrm{TNF}-\alpha)$. 
443 Several studies have shown that cannabinoid treatment could mitigate neuroinflammation

444 and damage produced by alcohol exposure during adulthood (see Table 3). In this sense,

445 OEA could prevent the neuroimmune response not only in rodent models (Antón et al., 446 2017; Orio et al., 2019) but also in humans (Antón et al., 2018; Orio et al., 2019).

447 Preclinical studies suggest that OEA not only prevents alcohol self-administration relapse 448 and reduces withdrawal signs of alcohol (Bilbao et al., 2016) but it also inhibits the 449 expression of proinflammatory markers in brain (Antón et al., 2017). Authors applied an 450 intragastric alcohol $(3 \mathrm{~g} / \mathrm{kg})$ treatment to male Wistar adult rats, followed by a repeated 4451 day binge paradigm until they reached an intoxicating blood alcohol levels (Antón et al., 452 2017). Consistent with this result, pre-treatment with OEA ( $5 \mathrm{mg} / \mathrm{kg}$, i.p.) prevented the 453 expression of inflammatory mediators induced by alcohol exposure in the frontal cortex, 454 such as HMGB1, TLR4, the myeloid differentiation protein-2 (MD2), and MyD88. 455 Additionally, they found that OEA pre-treatment blocked the HMGB1/TLR4/MyD88

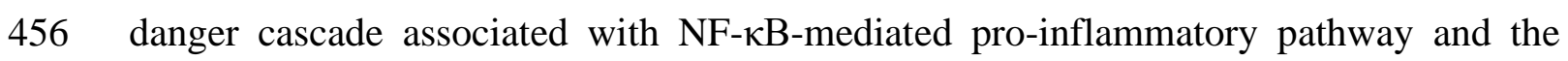
457 MCP-1 in frontal cortex in alcohol-binged rats (Antón et al., 2017), when the animals 458 were sacrificed 2-4h after last alcohol administration. In parallel, OEA (5mg/kg, i.p.) 459 could ameliorate alcohol-induced damage due to its neuroprotectant activity, reducing 460 caspase-3 activity, the expression of caspase 8, COX-2 and the iNOS (Antón et al., 2017), 461 molecules intimately involved with cell death and neurotoxicity associated with alcohol 462 (Liu et al., 2020; Pascual et al., 2007).

463 By contrast, other studies showed contradictory results regarding neuroinflammation 464 depending on both the dose and brain area studied. Whereas the OEA (10mg/kg, i.p.) 465 treatment per se increases the number of Iba1-positive cells in the HPC (Rivera et al., 466 2018), it decreases this cell population in the striatum (Rivera et al., 2019). Additionally, 467 OEA increases the Iba1- and iNOS-positive cells but decreases the vimentin 468 immunoreactivity in the striatum of alcohol-intoxicated and control rats, indicating a 469 reduction of astrogliosis (Rivera et al., 2019). Surprisingly, their results in the striatum 470 showed a reduced reactive astroglia despite the increased number of GFAP-positive cells. 471 Authors then hypothesized that these discrepancies either could be explained due to the 472 U-shape partial and dose-dependent OEA effects or due to the OEA-induced glial 473 recruitment and/or proliferation in these specific areas (Rivera et al., 2019). When the 
cannabinoid is co-administered with a 2 weeks of $10 \%$ alcohol liquid diet, both increase 475 the Iba1-positive cells in the striatum (Rivera et al., 2019) and HPC (Rivera et al., 2018), 476 promoting also an increasing of GFAP-positive and iNOS-positive cells in the striatum 477 (Rivera et al., 2019).

478 Moreover, OEA (5mg/kg; i.p.) is able to reduce the pro-inflammatory markers in blood. 479 Antón et al., (2017) found that this molecule could also reduce levels of TNF- $\alpha$ in blood 480 and IL-1 $\beta$ in blood and frontal cortex of alcohol-exposed rats, after a binge alcohol exposure (3g/kg; i.g.; 3 times/day for 4 days). Interestingly, a recent study in young adult alcohol binge drinkers during abstinence found that these inflammatory markers (TLR4, IL-1 $\beta$, COX-2, IL-6) positively correlated with the OEA levels in plasma, especially in females (Antón et al., 2018). Possible discrepancies could be due to the impossibility to establish which is the cause or the consequence in the relationship between inflammatory markers and alcohol consumption (María Antón et al., 2018). Noteworthy, patients were in abstinence and, probably, the upregulation of these biomarkers could be reflecting an anti-inflammatory response.

In the same line of OEA, the AEA (10mg/kg; i.p.) treatment increased both astrocytes iNOS-positive cells in the CA1 of HPC (Rivera et al., 2018) and GFAP- and Iba1immunoreactive cells in the striatum (Rivera et al., 2019) of alcohol-exposed rats. In fact, URB597 treatment also increased the number of Iba1-postive cell in HPC and induced minor morphological changes. However, the URB597 (0.3mg/kg; i.p.) treatment could restore the effects of alcohol-induced inflammatory and neurodegenerative process, since it was able to reduce mRNA levels of Iba1, TNF- $\alpha$, IL-6 and the MCP-1 and reduce iNOspositive cells, thus improving memory function in these rats (Rivera et al., 2018). Even though they found increased mRNA levels of TLR4, GFAP cells and the SDF$1 \alpha /$ CXCL1, they found an increasing hippocampal cell population expressing chemokine receptors $\mathrm{CX} 3 \mathrm{CR} 1, \mathrm{CCR} 2$ and $\mathrm{CCR} 4$. These receptors have been associated with

500 recruitment processes of immune cells. Therefore, authors hypothesized that URB597

$501(0.3 \mathrm{mg} / \mathrm{kg}$; i.p.) induced an anti-inflammatory microglial activation that might counteract 502 the alcohol-induced pro-inflammatory response (Rivera et al., 2018). These observations 503 run in parallel with the protective role of URB597 against alcohol intoxication. This 504 FAAH inhibitor might prevent the alcohol-induced neuroinflammation, since it reduces 505 alcohol consumption in the drinking in the dark paradigm, and preference after early 
withdrawal in mice (Zhou et al., 2017). Indeed, these results are supported by an increased alcohol intake and preference in mice modified with the FAAH human single-nucleotide polymorphism insertion (C385A) (Zhou et al., 2016), associated with a reduction of the FAAH activity and an enhancement of AEA levels in humans and mice (Dincheva et al.,

510 2015). Additionally, these effects could be blocked by a pre-treatment of a selective CB1 511 antagonist AM251 (Zhou et al., 2017, 2016). Despite its role in neuroinflammation, 512 URB597 failed to attenuate the number of necrotic cells within both dentate gyrus and 513 entorhinal cortex (Liput et al., 2017) in a rat binge model.

514 Phytocannabinoids are also important in the reduction of binge alcohol-induced brain 515 damage. Recently, Karoly et al., (2018) reported an association between circulating 516 proinflammatory cytokine IL-6 marker and alcohol consumption in alcohol regular 517 drinkers. Although variations in IL-1 $\beta$ were not found due to the low severity of the 518 consumers, alcohol dependent patients have shown an association between circulating IL$5191 \beta$ and alcohol consumption (Leclercq et al., 2014). Extended studies revealed a different 520 pattern of cytokines expression comparing alcohol and cannabis abusing patients. Among others, they observed a higher level of MCP-1, some interleukins (IL-16, IL-10, IL-309, IL-12-p40, IL-15), TNF- $\alpha$, tissue inhibitor of metalloproteinases 2 (TIMP-2), macrophage colony-stimulating factor (MCSF) and macrophage inflammatory protein $1 \alpha$

524 (MIP-1 $\alpha$ ) (Nair et al., 2015) obtained by array profiles from monocyte-derived dendritic cells. Moreover, there is a negative association between cannabis and IL- $1 \beta$ in cannabis users (Karoly et al., 2018), suggesting that the phytocannabinoids contained in cannabis could reduce inflammatory signals in users.

One of the phytocannabinoids that could have a neuroprotective action is $\mathrm{CBD}$, reducing apoptosis in both the entorhinal cortex and HPC of rats exposed to a binge-drinking alcohol model (Hamelink et al., 2005; Liput et al., 2013). In fact, the CBD neuroprotectant action observed in entorhinal cortex was similar when using a transdermal or i.p. delivery (Liput et al., 2013). However, the mechanisms that could mediate CBD neuroprotective effects still remain unknown due to the number of targets that CBD uses to exert its action.

Thus, eCBs and phytocannabinoids could promote their beneficial effects reducing neuroinflammatory, neurodegenerative and apoptotic signalling. Although OEA could increase some specific proinflammatory markers in a dose- and brain area-dependent manner, in general, this substance seems to procamote a proliferative and/or recruitment 
538 process in these areas, triggering an anti-inflammatory response. Additionally, we could 539 not discard opposite roles of cannabinoids due to different time-course in the experiments 540 or time-point in animals sacrifice. Moreover, it is necessary to consider possible different 541 sexual responses in the cannabinoid anti-inflammatory effect due to the fact that all 542 studies reported in the present section have been performed in male rats. To do so, it 543 should be mandatory performed parallel studies that asses the role of cannabinoids in 544 alcohol-induced neuroinflammatory processes in females.

545 Altogether, the results recruited above suggest that the activation of the expanded 546 endocannabinoid system could prevent alcohol-induced neurotoxic damage during 547 adulthood (see Table 2). 
549 neurodegeneration at adulthood.

\begin{tabular}{|c|c|c|c|c|c|c|c|}
\hline Reference & Animal model & $\begin{array}{c}\text { Alcohol } \\
\text { administration }\end{array}$ & $\begin{array}{l}\text { Cannabinoid } \\
\text { treatment }\end{array}$ & $\begin{array}{c}\text { Alcohol molecular } \\
\text { effects }\end{array}$ & $\begin{array}{c}\text { Cannabinoid molecular } \\
\text { effects }\end{array}$ & Synergic effects & $\begin{array}{c}\text { Behavioural } \\
\text { improvement/ } \\
\text { impairment }\end{array}$ \\
\hline $\begin{array}{l}\text { Antón et al. } \\
\text { (2017) }\end{array}$ & Male Wistar rats & $\begin{array}{l}\text { Majchrowicz } \\
\text { binge model } \\
\text { Binge alcohol (3 } \\
\text { g/kg; i.g.) } 3 \\
\text { times/day for } 4 \\
\text { days. } \\
\text { Control group } \\
\text { isocaloric } 5 \% \\
\text { dextrose } \\
\text { (equivalent to } 3 \\
\text { g/kg alcohol) } 3 \\
\text { times/day for } 4 \\
\text { days. }\end{array}$ & $\begin{array}{l}\text { OEA } \\
5 \mathrm{mg} / \mathrm{kg} \text {, i.p. } \\
\text { previous each } \\
\text { alcohol gavage }\end{array}$ & 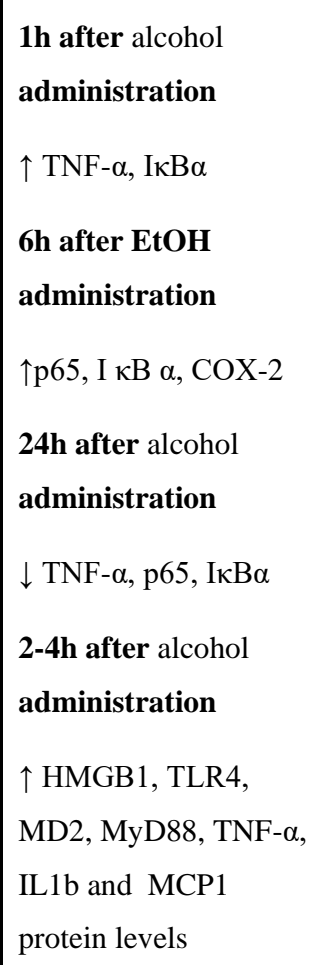 & No effects & $\begin{array}{l}\text { 2-4h after alcohol } \\
\text { administration } \\
\downarrow \text { HMGB1, TLR4, } \\
\text { MD2, MyD88, IL1b, } \\
\text { MCP1 and HNE protein } \\
\text { levels } \\
\downarrow \text { TLR4, p65, iNOS, } \\
\text { COX-2, Caspase-8 and } \\
\text { Caspase-3 mRNA } \\
\downarrow \text { Caspase } 3 \text { and p65 } \\
\text { activity }\end{array}$ & $\begin{array}{l}\text { OEA exerted } \\
\text { antidepressant-like } \\
\text { effects during acute } \\
\text { alcohol withdrawal } \\
\text { (forced swimming and } \\
\text { elevated plus maze). }\end{array}$ \\
\hline
\end{tabular}




\begin{tabular}{|c|c|c|c|c|c|c|c|}
\hline & & & & $\begin{array}{l}\uparrow \text { TLR4, IKB } \alpha \text {, iNOS, } \\
\text { HNE, Caspase- } 8 \text { and } \\
\text { Caspase } 3 \text { mRNA } \\
\uparrow \text { Caspase } 3 \text { activity }\end{array}$ & & & \\
\hline $\begin{array}{l}\text { Liput et al., } \\
\text { (2017) }\end{array}$ & $\begin{array}{l}\text { Male Sprague } \\
\text { Dawley rats }\end{array}$ & $\begin{array}{l}\text { Majchrowicz } \\
\text { binge model: } \\
\text { alcohol } 0-5 \mathrm{~g} / \mathrm{kg} \text {; } \\
\text { i.g., } 3 \text { times/day } \\
\text { for } 4 \text { days. } \\
\text { Control group } \\
\text { isocaloric } \\
\text { dextrose; } 3 \\
\text { times/day for } 4 \\
\text { days. }\end{array}$ & $\begin{array}{l}\text { URB597 } \\
0.3 \mathrm{mg} / \mathrm{kg} \text {, i.p. } \\
\text { Twice daily after } \\
\text { the third intubation } \\
\text { of alcohol /control } \\
\text { diet and continued } \\
\text { for the duration of } \\
\text { binge treatment. }\end{array}$ & $\begin{array}{l}\uparrow \mathrm{FJB}+\text { positive cells in } \\
\text { both DG and entorhinal } \\
\text { cortex }\end{array}$ & No effects & No effects & Not applicable \\
\hline $\begin{array}{l}\text { Liput et al., } \\
\text { (2013) }\end{array}$ & $\begin{array}{l}\text { Male Sprague } \\
\text { Dawley rats }\end{array}$ & $\begin{array}{l}\text { Majchrowicz } \\
\text { binge model: } \\
\text { alcohol 0-5 g/kg; } \\
\text { i.g., } 3 \text { times/day } \\
\text { for } 4 \text { days. } \\
\text { Control group } \\
\text { isocaloric }\end{array}$ & $\begin{array}{l}\text { CBD } \\
20 \mathrm{mg} / \mathrm{kg} \text { i.p. or } \\
2.5 \%(\mathrm{w} / \mathrm{w}) \\
\text { transdermal gel } \\
\text { application. }\end{array}$ & $\begin{array}{l}\uparrow \mathrm{FJB}+\text { positive cells in } \\
\text { entorhinal cortex }\end{array}$ & Not applicable & $\downarrow \mathrm{FJB}+$ positive cells & Not applicable \\
\hline
\end{tabular}




\begin{tabular}{|c|c|c|c|c|c|c|c|}
\hline & & $\begin{array}{l}\text { dextrose; } 3 \\
\text { times/day for } 4 \\
\text { days. }\end{array}$ & & & & & \\
\hline $\begin{array}{l}\text { Rivera } \text { et al., } \\
\text { (2018) }\end{array}$ & Male Wistar rats & $\begin{array}{l}\text { Ad libitum access } \\
\text { to } 11 \% \text { alcohol } \\
\text { (v/v) liquid diet } \\
\text { for } 2 \text { weeks } \\
\text { Control group } \\
\text { isocaloric } 14.7 \% \\
\text { (w/v) sucrose } \\
\text { liquid diet }\end{array}$ & $\begin{array}{l}\text { URB597 } \\
0.3 \mathrm{mg} / \mathrm{kg} \text {; i.p. } \\
\text { OEA } \\
10 \mathrm{mg} / \mathrm{kg} \text {; i.p. } \\
\text { AEA } \\
10 \mathrm{mg} / \mathrm{kg} \text {; i.p. } \\
\mathbf{A C E A} \\
3 \mathrm{mg} / \mathrm{kg} \text {; i.p. } \\
\mathbf{J W H 1 3 3} \\
0.2 \mathrm{mg} / \mathrm{kg} \text {; i.p. }\end{array}$ & $\begin{array}{l}\downarrow \text { iNOS }+ \text { cells in DG, } \\
\text { CA3 and CA1 } \\
\uparrow \text { Iba1, Tnfa, IL- } \\
6 \text { and MCP-1 mRNA } \\
\downarrow \text { CX3CR } 1+\text { cells in the } \\
\text { DG, CA3 and the } \\
\text { whole HPC } \\
\uparrow \text { CCR4+ cells }\end{array}$ & $\begin{array}{l}\text { All treatments: } \\
\downarrow \text { iNOS+cells within the } \\
\text { HPC } \\
\text { OEA, AEA, ACEA, } \\
\text { JWH133: } \\
\uparrow \text { GFAP+cells within the } \\
\text { HPC } \\
\text { OEA, JWH133: } \\
\downarrow \text { Iba1+cells within the } \\
\text { HPC } \\
\text { URB597, AEA: } \\
\uparrow \text { Iba1+cells within the } \\
\text { HPC } \\
\text { URB597 } \\
\downarrow \text { GFAP+cells within the } \\
\text { HPC } \\
\downarrow \text { Tnf } \alpha \text { mRNA }\end{array}$ & $\begin{array}{l}\text { OEA, JWH133: } \\
\uparrow \text { Iba1+cells within the } \\
\text { HPC } \\
\text { ACEA, JWH133: } \\
\uparrow \text { GFAP+cells in DG } \\
\text { URB597 } \\
\downarrow \text { iNOS+cells in CA3 } \\
\text { and CA1 and whole } \\
\text { HPC } \\
\downarrow \text { Ibal, Tnfa, IL- } \\
6 \text { and } M C P-1 \text { mRNA } \\
\uparrow T l r 4, \text { Gfap, Sdf- } \\
\text { la/Cxcl12 mRNA } \\
\uparrow \text { CX3CR } 1+, \text { CCR2 }+ \\
\text { and CCR4+ cells in the } \\
\text { HPC } \\
\uparrow C X 3 C R 1+\text { cells in the } \\
\text { DG, CA3, CA1 }\end{array}$ & $\begin{array}{l}\text { URB597 improves } \\
\text { memory (novel object } \\
\text { recognition) vs alcohol } \\
\text { group. }\end{array}$ \\
\hline
\end{tabular}




\begin{tabular}{|c|c|c|c|c|c|c|c|}
\hline & & & & & $\begin{array}{l}\uparrow \mathrm{CX} 3 \mathrm{CR} 1+\text { cells } \\
\text { population in } \mathrm{CA} 1 \\
\uparrow \text { the } \mathrm{CCR} 2+\text { cells } \\
\text { population in the DG, } \\
\mathrm{CA} 3, \mathrm{CA} 1 \\
\uparrow \mathrm{CCR} 4+\text { cells in } \mathrm{CA} 1 \\
\downarrow \mathrm{CXCR} 4+\text { cells in DG }\end{array}$ & $\begin{array}{l}\text { AEA } \\
\uparrow \text { iNOS+cells in CA1 }\end{array}$ & \\
\hline $\begin{array}{l}\text { Rivera et al., } \\
\text { (2019) }\end{array}$ & Male Wistar rats & $\begin{array}{l}\text { Ad libitum access } \\
\text { to } 10 \% \text { alcohol } \\
\text { (v/v) liquid diet } \\
\text { for } 2 \text { weeks } \\
\text { Control group } \\
\text { isocaloric } 14.7 \% \\
\text { (w/v) sucrose } \\
\text { liquid diet }\end{array}$ & $\begin{array}{l}\text { OEA } \\
10 \mathrm{mg} / \mathrm{kg} \text {, i.p. } \\
\text { AEA } \\
10 \mathrm{mg} / \mathrm{kg} \text {, i.p. } \\
\text { Daily treatment the } \\
\text { last } 5 \text { days of EtOH } \\
\text { exposure }\end{array}$ & $\begin{array}{l}\text { In striatum: } \\
\uparrow \text { Nape-pld mRNA } \\
\downarrow \text { iNOS+ cells } \\
\uparrow \text { Caspase- } 3 \\
\downarrow \text { caspase } 3+\text { cells } \\
\text { expressing Iba1 }\end{array}$ & $\begin{array}{l}\text { In striatum: } \\
\text { OEA } \\
\downarrow \text { vimentin+ cells } \\
\uparrow \text { Iba1+ and iNOS+ cells } \\
\downarrow \text { GFAP+/cleaved caspase } \\
3+\text { cells } \\
\text { AEA } \\
\uparrow \text { GFAP+ cells } \\
\uparrow \text { Iba } 1+\text { and iNOS+ cells } \\
\uparrow \text { Caspase-3 }\end{array}$ & $\begin{array}{l}\text { In striatum: } \\
\text { OEA } \\
\uparrow \text { GFAP+, Iba1+ and } \\
\text { iNOS+ cells } \\
\uparrow \text { Caspase } 3 \\
\downarrow \text { Caspase } 3+\text { cells } \\
\text { expressing Iba-1 } \\
\downarrow \text { GFAP+/cleaved } \\
\text { caspase } 3+\text { cells } \\
\text { AEA } \\
\uparrow \text { GFAP+ and Iba1+ } \\
\text { cells }\end{array}$ & $\begin{array}{l}\text { OEA and AEA } \\
\uparrow \text { sucrose intake } \\
\text { AEA } \\
\uparrow \text { EtOH intake. } \\
\text { OEA } \\
\uparrow \text { alcohol -induced } \\
\text { hypolocomotion }\end{array}$ \\
\hline
\end{tabular}




\begin{tabular}{|l|l|l|l|l|l|l|}
\hline & & & & & $\begin{array}{l}\downarrow \text { caspase } 3+\text { cells } \\
\text { expressing Iba1 }\end{array}$ \\
\hline
\end{tabular}

Alcohol molecular effects (alcohol group vs vehicle control group); Cannabinoid molecular effects (cannabinoid group vs vehicle control group); Synergic effect (alcohol + cannabinoid group vs alcohol group). Abbreviations: Arachidonyl-2-chloroethylamide (ACEA); Anandamide (AEA); Cannabidiol (CBD); Cyclooxigenase-2(COX2); Chemokine receptor (CCR); CX3C chemokine receptor 1 (CX3CR1); Dentate gyrus (DG); Frontal Cortex (FC); Fluoro-Jade B (FJB); Glial fibrillary acidic protein (GFAP); Glutathione (GSH); High mobility group box 1 (HMGB1); Hippocampus (HPC); Inducible nitric oxide synthase (iNOS); Ionized calcium binding adaptor molecule 1 (Iba1); Inhibitory kappa $\mathrm{B} \alpha(\mathrm{I} \kappa \mathrm{B} \alpha)$; Interleukin (IL); intragastrical (i.g.); intraperitoneal (i.p.); Monocyte chemoattractant protein 1 (MCP-1); Myeloid differentiation factor (MyD88); Oleoylamide (OEA); Chemokine stromal cell-derived factor 1 (SDF-1 $\alpha /$ CXCL1); Toll-like receptor (TLR); Tumour necrosis factor- $\alpha$ (TNF- $\alpha$ ). 
557 To conclude this section, it is crucial to highlight the controversial evidence regarding the cannabinoid-induced harmful/therapeutic effects on the modulation of damaging consequences associated with alcohol exposure. This lack of consistency among studies

560 is due to the breadth of the term "cannabinoid", including a lot of endogenous and

561 exogenous compounds. As we mentioned before, usage of CB1 agonists commonly

562 induce detrimental outcomes, whereas non-CB1 agonist could promote desirable anti-

563 inflammatory and neuroprotective effects. Thus, further preclinical studies are needed to

564 fully clarify the mechanisms of action underlying these promising cannabinoid-based 565 drugs.

\section{Putative mechanisms underlying cannabinoid modulation of alcohol-induced neuroinflammation}

568 Cannabinoids are able to modulate neuroinflammatory responses due to alcohol exposure. However, the mechanisms by which cannabinoids interfere with alcohol-induced intracellular signalling to counterbalance the inflammatory phenotype are complex and remain poorly understood.

\subsection{Inhibition of pro-inflammatory signalling}

573

The cannabinoid-induced interruption of the neuroinflammatory signalling can be mediated by cannabinoid receptor-dependent or -independent mechanisms as showed in Figure 1A.

\subsubsection{Cannabinoid receptors-dependent mechanisms}

Despite the extensive research regarding intracellular events triggered by cannabinoid receptor activation, the available information regarding putative interactions with pathways regulating immune response is often contradictory and solid conclusions are difficult to draw. Yang et al. (2013) found that activation of CB1 inhibits the TRPV1induced inflammatory response in corneal epithelial cells. Upon CB1 agonism, inhibition of cyclic adenosine monophosphate (cAMP) formation decreases the cAMP-dependent activation of protein kinase A (PKA). This decline translates in a reduction of the TRPV1 phosphorylation and activation, leading to a blunting in the inflammatory response. Ehrhart et al. (2005) demonstrated that the agonism of CB2 inhibits the IFN- $\gamma$-induced 
phosphorylation of JAK/STAT1 and decreases microglial production of proinflammatory

587 mediators, such as TNF- $\alpha$ and nitric oxide. JAK/STAT signalling is the main molecular pathway activated by ILs (Murray, 2007), promoting the expression of either proinflammatory or anti-inflammatory genes. Noteworthy, the most documented STAT upon the inflammatory signalling are the subtype STAT1 and STAT3. STAT1 induces the expression of pro-inflammatory molecules, whereas STAT3 mostly activates the expression of suppressors of cytokine signalling (SOCS) (Carey et al., 2012; Murray, 2006). However, the role of STAT3 in inflammation is still controversial, as the activation of this transcriptional factor has been shown to both repress the transcription of proinflammatory genes and promote cell apoptosis (Nabavi et al., 2019). Another study revealed that AEA-dependent microglial CB2 activation inhibits the phosphorylation of inhibitory kappa $\mathrm{B} \alpha(\mathrm{I} \kappa \mathrm{B} \alpha)$, preventing the translocation of $\mathrm{NF}-\kappa \mathrm{B}$ to the nucleus (Correa et al., 2010). In the same line, the activation of cannabinoid receptors, specially CB2, is related to the drive of activated microglia to more homeostatic phenotypes (Mecha et al., 2016). Therefore, cannabinoid receptors, through the inhibition of different components of the inflammatory signalling, might ameliorate the immune response caused by alcohol exposure.

\subsubsection{Cannabinoid receptors-independent mechanisms}

604 PPAR $\alpha$ and PPAR $\gamma$ are involved in the inhibition of the NF- $\kappa$ B and AP-1 pro605 inflammatory pathways, which are highly involved in the alcohol-induced inflammatory 606 response. When activated, these nuclear receptors are able to translocate to the nucleus 607 and bind to transcription factors to prevent their activity through a mechanism called 608 transrepression. Another form of transrepression is the binding of PPARs to the repressor 609 complex located on the promoter of inflammatory genes, therefore preventing their 610 transcription by NF- $\kappa$ B or AP-1 (Varga et al., 2011b). Du et al. (2011) inhibited the 611 phosphorylation of NF- $\mathrm{BB}$ and further COX-2 expression through the activation of 612 PPAR $\gamma$ by 2-AG and other PPAR $\gamma$ synthetic agonists in hippocampal neurons in vitro. 613 Another study by Yang et al. (2016) revealed that the activation of PPAR $\alpha$ by OEA 614 inhibits phosphorylation of $\mathrm{I} \kappa \mathrm{B} \alpha$, preventing the activation of NF- $\kappa \mathrm{B}$, in THP-1 615 monocytic cells. In the same study, activation of PPAR $\alpha$ by OEA was also found to inhibit 616 the ERK1/2/AP-1/STAT3 pathway, leading to the suppression of the inflammatory 617 response. 
618 On the other side of the balance, TRPV1 stimulation leads to the activation of pro619 inflammatory signalling pathways and a potential increase of alcohol-induce 620 neuroinflammation. Therefore, the modulation of this receptor could be of therapeutic 621 interest. When activated, intracellular Ca2+ rises in a TRPV-1 dependent manner leading 622 to the phosphorylation of ERK1/2 and the activation of the AP-1 transcription factor 623 (Backes et al., 2018) in H2C1 cell line. Furthermore, the TRPV1 stimulation-induced 624 increase in intracellular $\mathrm{Ca} 2+$ is thought to activate the transforming growth factor beta625 activated kinase 1 (TAK1) in human corneal epithelial cells, which will ultimately lead 626 to the activation of NF- $\mathrm{BB}$ and AP-1 (Wang et al., 2011; Yang et al., 2013), although this 627 mechanism needs to be further explored. Nevertheless, some studies have found 628 activation of TRPV1 to play neuroprotective and anti-inflammatory roles, although the 629 mechanism of action are not clear (Kong et al., 2017).

630 Microglial GPR55 stimulation has also been shown to activate ERK1/2 and NF- $\kappa B$, 631 leading to the transcription of pro-inflammatory mediators (Liu et al., 2015; Pietr et al., 632 2009). Therefore, the antagonism of GPR55 by cannabinoids, such as CBD (Kaplan et 633 al., 2017), could lead to more protective and homeostatic phenotypes to counterbalance 634 the alcohol-induced neuroinflammation.

635 In the CNS, alcohol-induced release of HMGB1 and other DAMPs activates TLR4, which 636 triggers different intracellular pathways leading to the activation of the main pro637 inflammatory transcription factors, NF- $\mathrm{B}$, AP-1 and IRF3, as well as STAT1. As we 638 have reviewed in this section, cannabinoids are able to interfere with the proper course of 639 this signalling in order to inhibit the pro-inflammatory response.

\subsection{Activation of anti-inflammatory signalling}

641 Despite a broad body of research that has focused on the pro-inflammatory signalling 642 inhibition, molecular mechanisms that regulate the transition of microglia from 643 detrimental states to phenotypes associated with CNS homeostasis are currently being 644 investigated. Modulation of the ECS has been proposed as a promising strategy against 645 pro-inflammatory microglial activation (Cristino et al., 2020; Franco and Fernández646 Suárez, 2015), as represented in Figure 1B. 
648 Evidence reveals that many cannabinoids can induce the expression of anti-inflammatory 649 cytokines, such as IL-4, IL-10 or TFG- $\beta$, in a chronic inflammatory context (Al-Ghezi et 650 al., 2019; Smith et al., 2000), which might be partially mediated by CB2 (Correa et al., 651 2010; Robinson et al., 2015). Although depending on different factors like the 652 inflammatory context, generally anti-inflammatory ILs bring balance toward STAT3 or 653 STAT6 activation, enhancing the function of suppressors of cytokine signalling (SOCS) 654 (Busch-Dienstfertig and González-Rodríguez, 2013; Carey et al., 2012). SOCS 655 expression mainly leads to the inhibition of the cytokine-JAK/STAT signalling, as a 656 negative feedback mechanism (Liau et al., 2018). In this respect, one study displayed that 657 CBD was able to strengthen the STAT3 activation in a LPS-induced pro-inflammatory 658 response, thereby promoting anti-inflammatory signalling in BV-2 microglia cells 659 (Kozela et al., 2010).

660 In addition, other authors have suggested non-canonical pathways by which the anti661 inflammatory IL-4 could directly activate the PPAR $\gamma$ (Li et al., 2014), which then 662 translocates to the nucleus to accomplish its biological function. In turn, some studies 663 revealed that the activation of these nuclear receptors by a specific agonist enhanced some 664 anti-inflammatory IL, such as IL-10, in microglia (Choi et al., 2017a, 2017b). 665 Nonetheless, other molecular pathways in which PPAR $\gamma$ is a key modulator could be 666 exploited.

\subsubsection{Activation of PPARY}

668

The PPAR $\gamma$ activation increases the expression of Arginase-1, which is a pro669 regenerative microglial marker (Fumagalli et al., 2018). Besides, a positive loop exists

670 between PPAR $\gamma$ and nuclear factor erythroid 2-related factor 2 (Nrf2). Therefore, PPAR $\gamma$ can upregulate Nrf2 and vice versa. Nrf2 is a transcriptional factor that activates the expression of numerous genes critical for the maintenance of redox homeostasis (Zhang et al., 2013). These proteins are necessary to inhibit the generation of reactive oxygen species (ROS) and mitigate neuroinflammation (Cai et al., 2018; Rojo et al., 2018). Moreover, CD36 microglial marker, which is under the regulation of both PPAR $\gamma$ and

676 Nrf2 (Yamanaka et al., 2012; Zhao et al., 2015), has been shown to facilitate the resolution of oxidative stress and neuroinflammation (Ballesteros et al., 2014; Huang et al., 2014). Interestingly, a recent study has demonstrated that the expression of CB2 in 
679 microglia is Nrf2-dependent (Galán-Ganga et al., 2020). As we mentioned above, CB2 680 agonism has also been proved to enhance anti-inflammatory IL expression (Correa et al., 681 2010; Robinson et al., 2015). In this context, it is established that both the exogenous 682 cannabinoids and the expanded endocannabinoid molecules can activate the PPAR $\gamma$ 683 (O'Sullivan, 2016) as well as the CB2. Furthermore, the modulation of these two 684 receptors has been proposed to exert neuroprotective and anti-inflammatory effects in the 685 alcohol context (Cippitelli et al., 2017; Nair et al., 2015). Thus, distinct cannabinoids 686 might be underpinning a promising mechanism involving PPAR $\gamma$-Nrf2-CB2 and anti687 inflammatory cytokines, to switch to alternative and pro-regenerative microglial 688 activation.

689 In the last decades, an epigenetic mechanism which involved the link between 690 microRNAs (miRNA) expression and alcohol-related disorders has been explored 691 (Ignacio et al., 2015; Mandal et al., 2018). Some studies have suggested that the 692 modulation of miRNAs expression plays a key role in the pathophysiologic inflammation 693 induced by alcohol exposure (Lippai et al., 2014, 2013). In regard to the inflammatory 694 response, other authors have proposed the implication of several miRNAs in promoting 695 pro-regenerative microglia phenotypes (Fumagalli et al., 2018; Guo et al., 2019). In fact, 696 a mechanistic study has confirmed that inhibition of pro-inflammatory cytokines 697 expression by the upregulation of miRNA-124 is mediated by the activation of PPAR $\gamma$ 698 (Wang et al., 2017). More evidence reported the effect of distinct miRNAs on the 699 microglia polarization, highlighting that miRNA-124 could promote the anti700 inflammatory phenotype (Guo et al., 2019). Interestingly, a recently reported mechanism 701 shows that cannabinoids can interfere with neuroinflammation through the modulation of 702 several miRNAs (Dinu et al., 2020). Another research group has identified a repertoire of 703 miRNAs that are regulated by cannabinoids in resting and LPS-activated microglia 704 (Juknat et al., 2019). Their results revealed that the modulated miRNAs are linked to 705 inflammatory pathways and Nrf2-mediated cellular stress. 

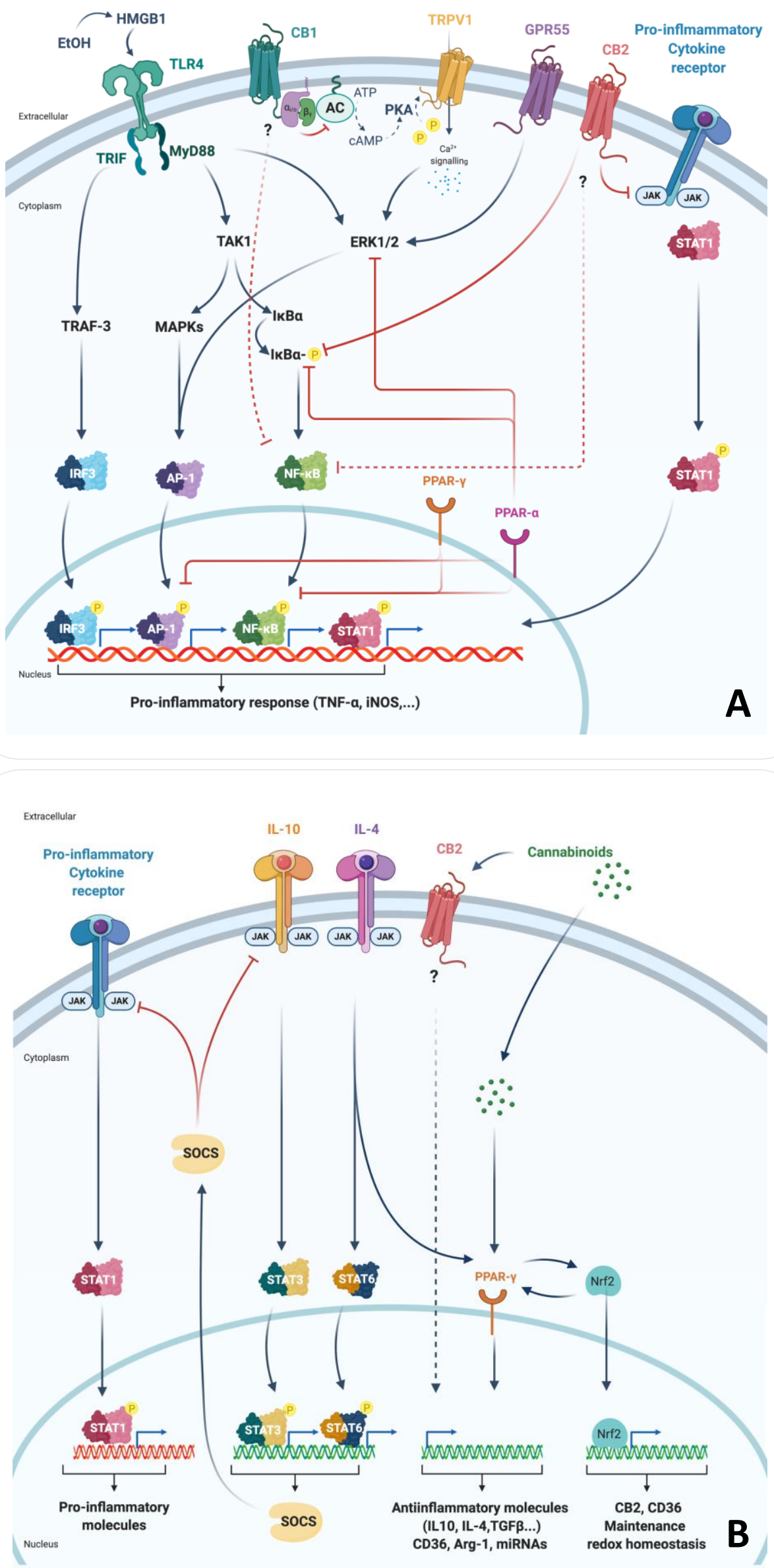

of pro-inflammatory signalling. Cannabinoid binding to different receptors from the expanded endocannabinoid system is able to interrupt pro-inflammatory signalling pathways. CB1 and CB2 activation leads to the inhibition of NF- $\kappa$ B. Besides, CB1 inhibits the TRPV1 and CB2 inhibits the JAK/STAT1 pro-inflammatory signalling pathways. PPAR $\alpha$ and PPAR $\gamma$ directly inhibit NF- $\mathrm{B}$ and AP-1.

$712 \operatorname{PPAR} \alpha$ also blocks the phosphorylation of ERK1/2. B) Anti-inflammatory signalling activated by 713 cannabinoids. Several endocannabinoids and exogenous cannabinoids can increase the expression of anti714 inflammatory cytokines (IL-10, IL-4, etc.) mainly through the activation of CB2 and PPAR $\gamma$. These 715 cytokines activate JAK/STAT toward an anti-inflammatory signalling, inducing the inhibition of pro716 inflammatory cytokines owing to the rising SOCS expression. PPAR $\gamma$ is able to activate Nrf2 and vice versa, promoting a positive anti-inflammatory feedback that allows an increasing expression of proregenerative mediators (CD36, Arg-1, redox-related enzymes, miRNAs, among some anti-inflammatory cytokines). Abbreviations: activator protein 1 (AP-1); arginase-1 (Arg-1); cannabinoid receptor 1 (CB1); cannabinoid receptor 2 (CB2); extracellular signal-regulated kinase (ERK); interleukin (IL); interferon regulatory factor 3 (IRF3); Janus kinase (JAK); nuclear factor erythroid 2-related factor 2 (Nrf2); nuclear factor kappa B (NF- $\mathrm{BB})$; microRNA (miRNA); peroxisome proliferator-activated receptor (PPAR); suppressor cytokine signalling (SOCS); signal transducer and activator transcription proteins (STAT); transforming growth factor beta (TFG $\beta$ ); transient receptor potential vanilloid 1 (TRPV1). Figure created with Biorender.com

726 In this section, we have hypothesised diverse mechanisms by which cannabinoid modulation may exert its anti-inflammatory effects in an alcohol context. On the one hand, we focused our research on the convergent molecules between pro-inflammatory pathways activated by alcohol in which cannabinoids might interfere, such as NF- $\kappa \mathrm{B}$. On

730 the other hand, we discussed complementary mechanisms based on the activation of anti731 inflammatory signalling which might cooperate to resolve the chronic deleterious 732 neuroinflammation caused by alcohol exposure. The studies mentioned above indicate 733 that cannabinoids are generally able to inhibit several components of pro-inflammatory 734 pathways that are activated after different insults. Furthermore, a number of studies have 735 shown the transition from detrimental microglial activation toward a regenerative 736 phenotype instigated by cannabinoid modulation. Yet, the majority of these studies have 737 been carried out upon common inflammatory insults and the factor that induces the 738 neuroinflammation is noteworthy for the type of pro-inflammatory pathways, which will 739 be activated. In this sense, further research is required to clarify the role of cannabinoids 740 in the field of alcohol-induced neuroinflammation, because there is scarce scientific 741 literature concerning mechanistic studies of how cannabinoids might act within alcohol742 dependent pro-inflammatory context. 


\section{Conclusions}

744 Alcohol exposure might trigger a series of pro-inflammatory and neurodegenerative 745 signalling pathways that drives the CNS to chronic and non-physiological stages. The 746 ECS is known to play a crucial role in the modulation of neuroinflammatory processes, 747 trending towards the resolution of the immune response. Although many studies have 748 focused on the anti-inflammatory properties of cannabinoids, only a few have used 749 alcohol as the etiological factor. Despite the fact that alcohol exposure derived effects 750 vary depending on the developmental state, we have found some consistencies across 751 adolescent and adult exposures to alcohol. Evidence suggests that direct agonism to CB1 752 is related to a worsening of the alcohol-induced detrimental effects. However, other 753 therapeutic approaches based on other components of the expanded endocannabinoid 754 system, such as PPAR $\gamma$ or the usage of OEA, have been shown to exert more promising 755 outcomes. The mechanisms through which cannabinoids are able to ameliorate the 756 alcohol-induced neuroinflammation are poorly understood. In this review, we propose a model where cannabinoids might counterbalance the immune response in alcohol contexts through the inhibition of pro-inflammatory and the stimulation of antiinflammatory signalling pathways. Therefore, cannabinoids act through multiple and complementary mechanisms in order to achieve a wider and more potent effect. Cannabinoid modulation represents an extremely interesting therapeutic target in alcoholinduced chronic neuroinflammation.

\section{Acknowledgements}

764 The authors are indebted to Dr. Miguel Ángel Luján for his invaluable help during the generation of the figures. The authors wish to thank Inés Gallego Landín for her English proofreading of the manuscript.

\section{Funding}

This study was funded by Ministerio de Economia y Competitividad (grant number SAF2016-75966-R-FEDER), Ministerio de Sanidad (Retic-ISCIII, RD16/017/010 and Plan Nacional sobre Drogas 2018/007). This study was also funded by FI-AGAUR (grant number 2019FI_B 00081) and FPI (grant number BES-2017-080066). The Department

772 of Experimental and Health Sciences (UPF) is an "Unidad de Excelencia María de Maeztu" funded by the MINECO (Ref. MDM-2014-0370). 


\section{References}

776

777

778

779

780

781

782

783

784

785

786

787

788

789

790

791

792

793

794

795

796

797

798

799

800

801

802

803

Achur, R.N., Freeman, W.M., Vrana, K.E., 2010. Circulating cytokines as biomarkers of alcohol abuse and alcoholism. J. Neuroimmune Pharmacol. 5, 83-91. https://doi.org/10.1007/s11481-009-9185-z

Agudelo, M., Yndart, A., Morrison, M., Figueroa, G., Muñoz, K., Samikkannu, T., Nair, M.P., 2013. Differential expression and functional role of cannabinoid genes in alcohol users. Drug Alcohol Depend. 133, 789-793. https://doi.org/10.1016/j.drugalcdep.2013.08.023

Al-Ghezi, Z.Z., Miranda, K., Nagarkatti, M., Nagarkatti, P.S., 2019. Combination of cannabinoids, $\Delta 9$-tetrahydrocannabinol and cannabidiol, ameliorates experimental multiple sclerosis by suppressing neuroinflammation through regulation of miRNA-mediated signaling pathways. Front. Immunol. 10, 1921. https://doi.org/10.3389/fimmu.2019.01921

Alen, F., Decara, J., Brunori, G., You, Z.-B., Bühler, K.-M., López-Moreno, J.A., Cippitelli, A., Pavon, F.J., Suárez, J., Gardner, E.L., de la Torre, R., Ciccocioppo, R., Serrano, A., Rodríguez de Fonseca, F., 2018. PPAR $\alpha / C B 1$ receptor dual ligands as a novel therapy for alcohol use disorder: Evaluation of a novel oleic acid conjugate in preclinical rat models. Biochem. Pharmacol. 157, 235-243. https://doi.org/10.1016/j.bcp.2018.09.008

Alfonso-Loeches, S., Pascual-Lucas, M., Blanco, A.M., Sanchez-Vera, I., Guerri, C., 2010. Pivotal Role of TLR4 Receptors in Alcohol-Induced Neuroinflammation and Brain Damage. J. Neurosci. 30, 8285-8295. https://doi.org/10.1523/JNEUROSCI.0976-10.2010

Alfonso-Loeches, S., Pascual, M., Guerri, C., 2013. Gender differences in alcoholinduced neurotoxicity and brain damage. Toxicology 311, 27-34. https://doi.org/10.1016/j.tox.2013.03.001

Alfonso-Loeches, S., Ureña-Peralta, J., Morillo-Bargues, M.J., Gómez-Pinedo, U., Guerri, C., 2016. Ethanol-Induced TLR4/NLRP3 Neuroinflammatory Response in Microglial Cells Promotes Leukocyte Infiltration Across the BBB. Neurochem. 
805

806

807

808

809

810

811

812

813

814

815

816

817

818

819

820

821

822

823

824

825

826

827

828

829

830

831

832

Antón, M., Alén, F., Gómez de Heras, R., Serrano, A., Pavón, F.J., Leza, J.C., GarcíaBueno, B., Rodríguez de Fonseca, F., Orio, L., 2017. Oleoylethanolamide prevents neuroimmune HMGB1/TLR4/NF-kB danger signaling in rat frontal cortex and depressive-like behavior induced by ethanol binge administration. Addict. Biol. 22, 724-741. https://doi.org/10.1111/adb.12365

Antón, M, Rodríguez-González, A., Ballesta, A., González, N., del Pozo, A., de Fonseca, F.R., Gómez-Lus, M.L., Leza, J.C., García-Bueno, B., Caso, J.R., Orio, L., 2018. Alcohol binge disrupts the rat intestinal barrier: the partial protective role of oleoylethanolamide. Br. J. Pharmacol. 175, 4464-4479. https://doi.org/10.1111/bph.14501

Antón, M., Rodríguez-González, A., Rodríguez-Rojo, I.C., Pastor, A., Correas, Á., Serrano, A., Ballesta, A., Alén, F., Gómez de Heras, R., de la Torre, R., Rodríguez de Fonseca, F., Orio, L., 2018. Increased plasma oleoylethanolamide and palmitoleoylethanolamide levels correlate with inflammatory changes in alcohol binge drinkers: the case of HMGB1 in women. Addict. Biol. 23, 1242-1250. https://doi.org/10.1111/adb.12580

Aoki, T., Narumiya, S., 2012. Prostaglandins and chronic inflammation. Trends Pharmacol. Sci. https://doi.org/10.1016/j.tips.2012.02.004

Araujo, D.J., Tjoa, K., Saijo, K., 2019. The Endocannabinoid System as a Window Into Microglial Biology and Its Relationship to Autism. Front. Cell. Neurosci. https://doi.org/10.3389/fncel.2019.00424

Atwood, B.K., Mackie, K., 2010. CB2: a cannabinoid receptor with an identity crisis. Br. J. Pharmacol. 160, 467-479. https://doi.org/10.1111/j.1476-5381.2010.00729.x

Aymerich, M.S., Aso, E., Abellanas, M.A., Tolon, R.M., Ramos, J.A., Ferrer, I., Romero, J., Fernández-Ruiz, J., 2018. Cannabinoid pharmacology/therapeutics in chronic degenerative disorders affecting the central nervous system. Biochem. Pharmacol. 157, 67-84. https://doi.org/10.1016/j.bcp.2018.08.016

Backes, T.M., Rössler, O.G., Hui, X., Grötzinger, C., Lipp, P., Thiel, G., 2018. 
Ballesteros, I., Cuartero, M.I., Pradillo, J.M., de la Parra, J., Perez-Ruiz, A., Corbi, A., Ricote, M., Hamilton, J.A., Sobrado, M., Vivancos, J., Nombela, F., Lizasoain, I., Moro, M.A., 2014. Rosiglitazone-induced CD36 up-regulation resolves inflammation by PPAR and 5-LO-dependent pathways. J. Leukoc. Biol. 95, 587598. https://doi.org/10.1189/jlb.0613326

Banks, W.A., Erickson, M.A., 2010. The blood-brain barrier and immune function and dysfunction. Neurobiol. Dis. https://doi.org/10.1016/j.nbd.2009.07.031

Bassi, M.S., Gentile, A., Iezzi, E., Zagaglia, S., Musella, A., Simonelli, I., Gilio, L., Furlan, R., Finardi, A., Marfia, G.A., Guadalupi, L., Bullitta, S., Mandolesi, G., Centonze, D., Buttari, F., 2019. Transient receptor potential vanilloid 1 modulates central inflammation in multiple sclerosis. Front. Neurol. 10. https://doi.org/10.3389/fneur.2019.00030

Bátkai, S., Mukhopadhyay, P., Horváth, B., Rajesh, M., Gao, R.Y., Mahadevan, A., Amere, M., Battista, N., Lichtman, A.H., Gauson, L.A., Maccarrone, M., Pertwee, R.G., Pacher, P., 2012. $\Delta 8$-Tetrahydrocannabivarin prevents hepatic ischaemia/reperfusion injury by decreasing oxidative stress and inflammatory responses through cannabinoid CB2 receptors. Br. J. Pharmacol. 165, 2450-2461. https://doi.org/10.1111/j.1476-5381.2011.01410.x

Bellozi, P.M.Q., Pelição, R., Santos, M.C., Lima, I.V.A., Saliba, S.W., Vieira, É.L.M., Campos, A.C., Teixeira, A.L., de Oliveira, A.C.P., Nakamura-Palacios, E.M., Rodrigues, L.C.M., 2019. URB597 ameliorates the deleterious effects induced by binge alcohol consumption in adolescent rats. Neurosci. Lett. 711, 134408. https://doi.org/10.1016/j.neulet.2019.134408

Bilbao, A., Serrano, A., Cippitelli, A., Pavón, F.J., Giuffrida, A., Suárez, J., GarcíaMarchena, N., Baixeras, E., Gómez de Heras, R., Orio, L., Alén, F., Ciccocioppo, R., Cravatt, B.F., Parsons, L.H., Piomelli, D., Rodríguez de Fonseca, F., 2016. Role of the satiety factor oleoylethanolamide in alcoholism. Addict. Biol. 21, 859872. https://doi.org/10.1111/adb.12276 
863 Bisogno, T., Howell, F., Williams, G., Minassi, A., Cascio, M.G., Ligresti, A., Matias,

864

865

866

867

868

869

870

871

872

873

874

875

876

877

878

879

880

881

882

883

884

885

886

887

888

889

890

891 I., Schiano-Moriello, A., Paul, P., Williams, E.-J., Gangadharan, U., Hobbs, C., Di Marzo, V., Doherty, P., 2003. Cloning of the first sn1-DAG lipases points to the spatial and temporal regulation of endocannabinoid signaling in the brain. J. Cell Biol. 163, 463-8. https://doi.org/10.1083/jcb.200305129

Blednov, Y.A., Benavidez, J.M., Black, M., Ferguson, L.B., Schoenhard, G.L., Goate, A.M., Edenberg, H.J., Wetherill, L., Hesselbrock, V., Foroud, T., Adron Harris, R., 2015. Peroxisome Proliferator-Activated Receptors $\alpha$ and $\gamma$ are Linked with Alcohol Consumption in Mice and Withdrawal and Dependence in Humans. Alcohol. Clin. Exp. Res. 39, 136-145. https://doi.org/10.1111/acer.12610

Busch-Dienstfertig, M., González-Rodríguez, S., 2013. IL-4, JAK-STAT signaling, and pain. JAK-STAT 2, e27638. https://doi.org/10.4161/jkst.27638

Cabral, G.A., Griffin-Thomas, L., 2009. Emerging role of the cannabinoid receptor CB 2 in immune regulation: therapeutic prospects for neuroinflammation. Expert Rev. Mol. Med. 11, e3. https://doi.org/10.1017/S1462399409000957

Cai, W., Yang, T., Liu, H., Han, L., Zhang, K., Hu, X., Zhang, X., Yin, K.-J., Gao, Y., Bennett, M.V.L., Leak, R.K., Chen, J., 2018. Peroxisome proliferator-activated receptor $\gamma(\operatorname{PPAR} \gamma)$ : A master gatekeeper in CNS injury and repair. Prog. Neurobiol. 163-164, 27-58. https://doi.org/10.1016/j.pneurobio.2017.10.002

Capuron, L., Miller, A.H., 2011. Immune system to brain signaling: Neuropsychopharmacological implications. Pharmacol. Ther. 226-38. https://doi.org/10.1016/j.pharmthera.2011.01.014

Carey, A.J., Tan, C.K., Ulett, G.C., 2012. Infection-induced IL-10 and JAK-STAT. JAK-STAT 1, 159-167. https://doi.org/10.4161/jkst.19918

Cassano, T., Calcagnini, S., Pace, L., Marco, F. De, Romano, A., Gaetani, S., 2017. Cannabinoid receptor 2 signaling in neurodegenerative disorders: From pathogenesis to a promising therapeutic target. Front. Neurosci. https://doi.org/10.3389/fnins.2017.00030

Chiurchiù, V., Leuti, A., Maccarrone, M., 2018. Bioactive lipids and chronic 
892

Chiurchiù, V., Leuti, A., Maccarrone, M., 2015. Cannabinoid Signaling and Neuroinflammatory Diseases: A Melting pot for the Regulation of Brain Immune Responses. J. Neuroimmune Pharmacol. 10, 268-280.

https://doi.org/10.1007/s11481-015-9584-2

Choi, M.J., Lee, E.J., Park, J.S., Kim, S.N., Park, E.M., Kim, H.S., 2017a. Antiinflammatory mechanism of galangin in lipopolysaccharide-stimulated microglia: Critical role of PPAR- $\gamma$ signaling pathway. Biochem. Pharmacol. 144, 120-131. https://doi.org/10.1016/j.bcp.2017.07.021

Choi, M.J., Park, J.S., Park, J.E., Kim, Han Su, Kim, Hee Sun, 2017b. Galangin suppresses pro-inflammatory gene expression in polyinosinic-polycytidylic acidstimulated microglial cells. Biomol. Ther. 25, 641-647. https://doi.org/10.4062/biomolther.2017.173

Cippitelli, A., Domi, E., Ubaldi, M., Douglas, J.C., Li, H.W., Demopulos, G., Gaitanaris, G., Roberto, M., Drew, P.D., Kane, C.J.M., Ciccocioppo, R., 2017. Protection against alcohol-induced neuronal and cognitive damage by the PPAR $\gamma$ receptor agonist pioglitazone. Brain. Behav. Immun. 64, 320-329. https://doi.org/10.1016/j.bbi.2017.02.001

Coleman, L.G., Crews, F.T., 2018. Innate Immune Signaling and Alcohol Use Disorders. Handbook of Experimental Pharmacology. Springer New York LLC. 369-396. https://doi.org/10.1007/164_2018_92

Correa, F., Docagne, F., Mestre, L., Loría, F., Hernangómez, M., Borrell, J., Guaza, C., 2007. Cannabinoid system and neuroinflammation: Implications for multiple sclerosis. NeuroImmunoModulation. 182-187. https://doi.org/10.1159/000110644

Correa, F., Hernangómez, M., Mestre, L., Loría, F., Spagnolo, A., Docagne, F., Di Marzo, V., Guaza, C., 2010. Anandamide enhances IL-10 production in activated microglia by targeting CB 2 receptors: Roles of ERK1/2, JNK, and NF-kB. Glia 58, 135-147. https://doi.org/10.1002/glia.20907 
921 Cravatt, B.F., Giang, D.K., Mayfield, S.P., Boger, D.L., Lerner, R.A., Gilula, N.B.,

922

923

924

925

926

927

928

929

930

931

932

933

934

935

936

937

938

939

940

941

942

943

944

945

946

947

948

949 1996. Molecular characterization of an enzyme that degrades neuromodulatory fatty-acid amides. Nature 384, 83-87. https://doi.org/10.1038/384083a0

Crews, F.T., Bechara, R., Brown, L.A., Guidot, D.M., Mandrekar, P., Oak, S., Qin, L., Szabo, G., Wheeler, M., Zou, J., 2006. Cytokines and alcohol. Alcoholism: Clinical and Experimental Research. 30, 720-730. https://doi.org/10.1111/j.15300277.2006.00084.x

Crews, F.T., Vetreno, R.P., 2016. Mechanisms of neuroimmune gene induction in alcoholism. Psychopharmacology (Berl). 233, 1543-57. https://doi.org/10.1007/s00213-015-3906-1

Crews, F.T., Vetreno, R.P., 2014. Neuroimmune basis of alcoholic brain damage. Int. Rev. Neurobiol. 118, 315-57. https://doi.org/10.1016/B978-0-12-801284-0.000105

Cristino, L., Bisogno, T., Di Marzo, V., 2020. Cannabinoids and the expanded endocannabinoid system in neurological disorders. Nat. Rev. Neurol. 16, 9-29. https://doi.org/10.1038/s41582-019-0284-z

Croxford, J.L., Yamamura, T., 2005. Cannabinoids and the immune system: Potential for the treatment of inflammatory diseases? J. Neuroimmunol. 166, 3-18. https://doi.org/10.1016/j.jneuroim.2005.04.023

Cruz, C., Meireles, M., Silva, S.M., 2017. Chronic ethanol intake induces partial microglial activation that is not reversed by long-term ethanol withdrawal in the rat hippocampal formation. Neurotoxicology 60, 107-115.

https://doi.org/10.1016/J.NEURO.2017.04.005

D’Mello, C., Swain, M.G., 2017. Immune-to-brain communication pathways in inflammation-associated sickness and depression. Current Topics in Behavioral Neurosciences. Springer Verlag. 31, 73-94. https://doi.org/10.1007/7854_2016_37

Dantzer, R., O’Connor, J.C., Freund, G.G., Johnson, R.W., Kelley, K.W., 2008. From inflammation to sickness and depression: When the immune system subjugates the brain. Nat. Rev. Neurosci. 9, 46-56. https://doi.org/10.1038/nrn2297 
950 De Petrocellis, L., Ligresti, A., Moriello, A.S., Allarà, M., Bisogno, T., Petrosino, S.,

951

952

953

954

955

956

957

958

959

960

961

962

963

964

965

966

967

968

969

970

971

972

973

974

975

976

977 Stott, C.G., Di Marzo, V., 2011. Effects of cannabinoids and cannabinoid-enriched Cannabis extracts on TRP channels and endocannabinoid metabolic enzymes. Br. J. Pharmacol. 163, 1479-94. https://doi.org/10.1111/j.1476-5381.2010.01166.x

de Timary, P., Stärkel, P., Delzenne, N.M., Leclercq, S., 2017. A role for the peripheral immune system in the development of alcohol use disorders? Neuropharmacology 122, 148-160. https://doi.org/10.1016/j.neuropharm.2017.04.013

Dennis, E.A., Norris, P.C., 2015. Eicosanoid storm in infection and inflammation. Nat. Rev. Immunol. 15, 511-523. https://doi.org/10.1038/nri3859

Devane, W.A., Dysarz, F.A., Johnson, M.R., Melvin, L.S., Howlett, A.C., 1988. Determination and characterization of a cannabinoid receptor in rat brain. Mol. Pharmacol. 34, 605-613.

Di Marzo, V., 2018. New approaches and challenges to targeting the endocannabinoid system. Nat. Rev. Drug Discov. 17, 623-639. https://doi.org/10.1038/nrd.2018.115

Di Marzo, V., Bisogno, T., De Petrocellis, L., 2000. Endocannabinoids: new targets for drug development. Curr. Pharm. Des. 6, 1361-1380.

Di Marzo, V., Melck, D., Bisogno, T., De Petrocellis, L., 1998. Endocannabinoids: Endogenous cannabinoid receptor ligands with neuromodulatory action. Trends Neurosci. 21, 521-528. https://doi.org/10.1016/S0166-2236(98)01283-1

Dincheva, I., Drysdale, A.T., Hartley, C.A., Johnson, D.C., Jing, D., King, E.C., Ra, S., Gray, J.M., Yang, R., DeGruccio, A.M., Huang, C., Cravatt, B.F., Glatt, C.E., Hill, M.N., Casey, B.J., Lee, F.S., 2015. FAAH genetic variation enhances frontoamygdala function in mouse and human. Nat. Commun. 6. https://doi.org/10.1038/ncomms7395

Dinh, T.P., Carpenter, D., Leslie, F.M., Freund, T.F., Katona, I., Sensi, S.L., Kathuria, S., Piomelli, D., 2002. Brain monoglyceride lipase participating in endocannabinoid inactivation. Proc. Natl. Acad. Sci. U. S. A. 99, 10819-10824. https://doi.org/10.1073/pnas.152334899 
978

979

980

981

982

983

984

985

986

987

988

989

990

991

992

993

994

995

996

997

998

999

1000

1001

1002

1003

1004

1005

1006

1007

Dinu, A.R., Rogobete, A.F., Bratu, T., Popovici, S.E., Bedreag, O.H., Papurica, M., Bratu, L.M., Sandesc, D., 2020. Cannabis Sativa Revisited-Crosstalk between microRNA Expression, Inflammation, Oxidative Stress, and Endocannabinoid Response System in Critically Ill Patients with Sepsis. Cells 9, 307. https://doi.org/10.3390/cells9020307

Donvito, G., Nass, S.R., Wilkerson, J.L., Curry, Z.A., Schurman, L.D., Kinsey, S.G., Lichtman, A.H., 2018. The Endogenous Cannabinoid System: A Budding Source of Targets for Treating Inflammatory and Neuropathic Pain. Neuropsychopharmacology 43, 52-79. https://doi.org/10.1038/npp.2017.204

Du, H., Chen, X., Zhang, J., Chen, C., 2011. Inhibition of COX-2 expression by endocannabinoid 2-arachidonoylglycerol is mediated via PPAR-g. Br. J. Pharmacol. 163, 1533. https://doi.org/10.1111/bph.2011.163.issue-7

Ehrhart, J., Obregon, D., Mori, T., Hou, H., Sun, N., Bai, Y., Klein, T., Fernandez, F., Tan, J., Douglas Shytle, R., 2005. Stimulation of cannabinoid receptor 2 (CB2) suppresses microglial activation. 58, 118-129. https://doi.org/10.1186/1742-2094$2-29$

Erickson, E.K., Grantham, E.K., Warden, A.S., Harris, R.A., 2019. Neuroimmune signaling in alcohol use disorder. Pharmacol. Biochem. Behav. 177, 34-60. https://doi.org/10.1016/j.pbb.2018.12.007

Fakhfouri, G., Ahmadiani, A., Rahimian, R., Grolla, A.A., Moradi, F., Haeri, A., 2012. WIN55212-2 attenuates amyloid-beta-induced neuroinflammation in rats through activation of cannabinoid receptors and PPAR-g pathway. Neuropharmacology 63, 653-666. https://doi.org/10.1016/j.neuropharm.2012.05.013

Fernandez-Lizarbe, S., Pascual, M., Guerri, C., 2009. Critical role of TLR4 response in the activation of microglia induced by ethanol. J. Immunol. 183, 4733-44. https://doi.org/10.4049/jimmunol.0803590

Ferrier, L., Bérard, F., Debrauwer, L., Chabo, C., Langella, P., Buéno, L., Fioramonti, J., 2006. Impairment of the intestinal barrier by ethanol involves enteric microflora and mast cell activation in rodents. Am. J. Pathol. 168, 1148-1154. https://doi.org/10.2353/ajpath.2006.050617 
Franco, R., Fernández-Suárez, D., 2015. Alternatively activated microglia and macrophages in the central nervous system. Prog. Neurobiol. 131, 65-86. https://doi.org/10.1016/j.pneurobio.2015.05.003

Freund, A.F., Katona, A., Piomelli, D., 2003. Role of Endogenous Cannabinoids in Synaptic Signaling. 83,1017-1066. https://doi.org/10.1152/physrev.00004.2003.Research

Frontera, J.L., Gonzalez Pini, V.M., Messore, F.L., Brusco, A., 2018. Exposure to cannabinoid agonist WIN 55,212-2 during early adolescence increases alcohol preference and anxiety in CD1 mice. Neuropharmacology 137, 268-274. https://doi.org/10.1016/j.neuropharm.2018.05.018

Fumagalli, M., Lombardi, M., Gressens, P., Verderio, C., 2018. How to reprogram microglia toward beneficial functions. 66, 2531-2549. Glia. https://doi.org/10.1002/glia.23484

Galán-Ganga, M., del Río, R., Jiménez-Moreno, N., Díaz-Guerra, M., Lastres-Becker, I., 2020. Cannabinoid CB2 Receptor Modulation by the Transcription Factor NRF2 is Specific in Microglial Cells. Cell. Mol. Neurobiol. 40, 167-177. https://doi.org/10.1007/s10571-019-00719-y

Gao, B., Seki, E., Brenner, D.A., Friedman, S., Cohen, J.I., Nagy, L., Szabo, G., Zakhari, S., 2011. Innate immunity in alcoholic liver disease. Am. J. Physiol. Gastrointest. Liver Physiol. 300, 516-525. https://doi.org/10.1152/ajpgi.00537.2010

Gilhus, N.E., Deuschl, G., 2019. Neuroinflammation — a common thread in neurological disorders. Nat. Rev. Neurol. https://doi.org/10.1038/s41582-0190227-8

González-Reimers, E., Fernández-Rodríguez, C.M., Santolaria-Fernández, F., VegaPrieto, M.J. de la, Martín-González, C., Gómez-Rodríguez, M.Á., Alemán-Valls, M.R., Rodríguez-Gaspar, M., 2011. Interleukin-15 and Other Myokines in Chronic Alcoholics. Alcohol Alcohol. 46, 529-533. https://doi.org/10.1093/alcalc/agr064

Grabner, G.F., Zimmermann, R., Schicho, R., Taschler, U., 2017. Monoglyceride lipase 
1037

1038

1039

1040

1041

1042

1043

1044

1045

1046

1047

1048

1049

1050

1051

1052

1053

1054

1055

1056

1057

1058

1059

1060

1061

1062

1063

1064

1065

as a drug target: At the crossroads of arachidonic acid metabolism and endocannabinoid signaling. Pharmacol. Ther. 175, 35-46. https://doi.org/10.1016/j.pharmthera.2017.02.033

Greenhalgh, A.D., David, S., Bennett, F.C., 2020. Immune cell regulation of glia during CNS injury and disease. Nat. Rev. Neurosci.21, 139-152. https://doi.org/10.1038/s41583-020-0263-9

Guerri, C., Pascual, M., 2019. Impact of neuroimmune activation induced by alcohol or drug abuse on adolescent brain development. Int. J. Dev. Neurosci. 77, 89-98. https://doi.org/10.1016/j.ijdevneu.2018.11.006

Guo, Y., Hong, W., Wang, X., Zhang, P., Körner, H., Tu, J., Wei, W., 2019. MicroRNAs in microglia: How do MicroRNAs affect activation, inflammation, polarization of microglia and mediate the interaction between microglia and glioma? Front. Mol. Neurosci. https://doi.org/10.3389/fnmol.2019.00125

Hamelink, C., Hampson, A., Wink, D.A., Eiden, L.E., Eskay, R.L., 2005. Comparison of Cannabidiol, Antioxidants, and Diuretics in Reversing Binge Ethanol-Induced Neurotoxicity. J. pharmacoly Exp. Ther. 314, 780-788. https://doi.org/10.1124/jpet.105.085779

Hansen, H.S., Rosenkilde, M.M., Holst, J.J., Schwartz, T.W., 2012. GPR119 as a fat sensor. Trends Pharmacol. Sci. 33, 374-381. https://doi.org/10.1016/j.tips.2012.03.014

He, J., Crews, F.T., 2008. Increased MCP-1 and microglia in various regions of the human alcoholic brain. Exp. Neurol. 210, 349-358. https://doi.org/10.1016/j.expneurol.2007.11.017

Heberlein, A., Käser, M., Lichtinghagen, R., Rhein, M., Lenz, B., Kornhuber, J., Bleich, S., Hillemacher, T., 2014. TNF- $\alpha$ and IL-6 serum levels: Neurobiological markers of alcohol consumption in alcohol-dependent patients? Alcohol 48, 671-676. https://doi.org/10.1016/j.alcohol.2014.08.003

Huang, S.C.C., Everts, B., Ivanova, Y., O’Sullivan, D., Nascimento, M., Smith, A.M., Beatty, W., Love-Gregory, L., Lam, W.Y., O’Neill, C.M., Yan, C., Du, H., 

Abumrad, N.A., Urban, J.F., Artyomov, M.N., Pearce, E.L., Pearce, E.J., 2014. Cell-intrinsic lysosomal lipolysis is essential for alternative activation of macrophages. Nat. Immunol. 15, 846-855. https://doi.org/10.1038/ni.2956

Ignacio, C., Hicks, S.D., Burke, P., Lewis, L., Szombathyne-Meszaros, Z., Middleton, F.A., 2015. Alterations in serum microRNA in humans with alcohol use disorders impact cell proliferation and cell death pathways and predict structural and functional changes in brain. BMC Neurosci. 16, 55. https://doi.org/10.1186/s12868-015-0195-X

Irving, A.J., McDonald, N.A., Harkany, T., 2008. CB1 cannabinoid receptors: Molecular biology, second messenger coupling and polarized trafficking in neurons. Cannabinoids and the Brain. Springer US. 59-73. https://doi.org/10.1007/978-0-387-74349-3_5

Jeon, Y.J., Yang, K.H., Pulaski, J.T., Kaminski, N.E., 1996. Attenuation of inducible nitric oxide synthase gene expression by $\Delta 9$ - tetrahydrocannabinol is mediated through the inhibition of nuclear factor- $\kappa \mathrm{B} /$ Rel activation. Mol. Pharmacol. 50, 334-341.

Johns, D.G., Behm, D.J., Walker, D.J., Ao, Z., Shapland, E.M., Daniels, D.A., Riddick, M., Dowell, S., Staton, P.C., Green, P., Shabon, U., Bao, W., Aiyar, N., Yue, T.-L., Brown, A.J., Douglas, S.A., 2007. The novel endocannabinoid receptor GPR55 is activated by atypical cannabinoids but does not mediate their vasodilator effects. Br. J. Pharmacol. 152, 825-831. https://doi.org/10.1038/sj.bjp.0707419

Juknat, A., Gao, F., Coppola, G., Vogel, Z., Kozela, E., 2019. miRNA expression profiles and molecular networks in resting and LPS-activated BV-2 microgliaEffect of cannabinoids. PLoS One 14, e0212039. https://doi.org/10.1371/journal.pone.0212039

Kane, C.J.M., Phelan, K.D., Douglas, J.C., Wagoner, G., Johnson, J.W., Xu, J., Phelan, P.S., Drew, P.D., 2014. Effects of Ethanol on Immune Response in the Brain: Region-Specific Changes in Adolescent Versus Adult Mice. Alcohol. Clin. Exp. Res. 38, 384-391. https://doi.org/10.1111/acer.12244

1095 Kaplan, B.L.F., 2013. The role of CB1 in immune modulation by cannabinoids. 
Kaplan, J.S., Stella, N., Catterall, W.A., Westenbroek, R.E., 2017. Cannabidiol attenuates seizures and social deficits in a mouse model of Dravet syndrome. Proc. Natl. Acad. Sci. 114, 11229-11234. https://doi.org/10.1073/pnas.1711351114

1100

Kapoor, M., Wang, J.C., Farris, S.P., Liu, Y., McClintick, J., Gupta, I., Meyers, J.L., Bertelsen, S., Chao, M., Nurnberger, J., Tischfield, J., Harari, O., Zeran, L., Hesselbrock, V., Bauer, L., Raj, T., Porjesz, B., Agrawal, A., Foroud, T., Edenberg, H.J., Mayfield, R.D., Goate, A., 2019. Analysis of whole genome-

Karoly, H.C., Bidwell, L.C., Mueller, R.L., Hutchison, K.E., 2018. Investigating the transcriptomic organization in brain to identify genes associated with alcoholism. Relationships Between Alcohol Consumption, Cannabis Use, and Circulating Cytokines: A Preliminary Analysis. Alcohol. Clin. Exp. Res. 42, 531-539.

Katona, I., ta Sperlá gh, B., Sík, A., Kä falvi, A., Sylvester Vizi, E., Mackie, K., Freund, T.F., 1999. Presynaptically Located CB1 Cannabinoid Receptors Regulate GABA

Katona, I., Urbán, G.M., Wallace, M., Ledent, C., Jung, K.M., Piomelli, D., Mackie, K., Release from Axon Terminals of Specific Hippocampal Interneurons. J. Neurosci.19, 4544-4558. https://doi.org./10.1523/JNEUROSCI.19-11-04544.1999

Kelly, R., Joers, V., Tansey, M.G., McKernan, D.P., Dowd, E., 2020. Microglial Freund, T.F., 2006. Molecular composition of the endocannabinoid system at glutamatergic synapses. J. Neurosci. 26, 5628-5637. https://doi.org/10.1523/JNEUROSCI.0309-06.2006 and therapeutic potential of TRPV1 in the neuro-immune axis. Brain. Behav. Immun. 64, 354-366. https://doi.org/10.1016/j.bbi.2017.03.007 
1125 Kozela, E., Pietr, M., Juknat, A., Rimmerman, N., Levy, R., Vogel, Z., 2010.

1126 Cannabinoids $\Delta 9$-Tetrahydrocannabinol and Cannabidiol Differentially Inhibit

1127 the Lipopolysaccharide-activated NF- $\kappa$ B and Interferon- $\beta /$ STAT Proinflammatory

1128 Pathways in BV-2 Microglial Cells. J. Biol. Chem. 285, 1616-1626.

1129 https://doi.org/10.1074/jbc.M109.069294

1130 Kyzar, E.J., Floreani, C., Teppen, T.L., Pandey, S.C., 2016. Adolescent Alcohol

1131 Exposure: Burden of Epigenetic Reprogramming, Synaptic Remodeling, and Adult

1132 Psychopathology. Front. Neurosci. 10. https://doi.org/10.3389/fnins.2016.00222

1133 Lamont, M.G., McCallum, P., Head, N., Blundell, J., Weber, J.T., 2020. Binge drinking

1134 in male adolescent rats and its relationship to persistent behavioral impairments

1135 and elevated proinflammatory/proapoptotic proteins in the cerebellum.

1136 Psychopharmacology (Berl). 23, 1305-1315. https://doi.org/10.1007/s00213-020-

$1137 \quad 05458-3$

1138 Lauckner, J.E., Jensen, J.B., Chen, H.Y., Lu, H.C., Hille, B., Mackie, K., 2008. GPR55

1139 is a cannabinoid receptor that increases intracellular calcium and inhibits $\mathrm{M}$

1140 current. Proc. Natl. Acad. Sci. U. S. A. 105, 2699-2704.

$1141 \quad$ https://doi.org/10.1073/pnas.0711278105

1142 Leclercq, S., Cani, P.D., Neyrinck, A.M., Stärkel, P., Jamar, F., Mikolajczak, M., 1143 Delzenne, N.M., De Timary, P., 2012. Role of intestinal permeability and 1144 inflammation in the biological and behavioral control of alcohol-dependent 1145 subjects. Brain. Behav. Immun. 26, 911-918.

$1146 \quad$ https://doi.org/10.1016/j.bbi.2012.04.001

1147 Leclercq, S., De Saeger, C., Delzenne, N., de Timary, P., Stärkel, P., 2014. Role of

1148 inflammatory pathways, blood mononuclear cells, and gut-derived bacterial

1149 products in alcohol dependence. Biol. Psychiatry 76, 725-33.

1150 https://doi.org/10.1016/j.biopsych.2014.02.003

1151 Lewohl, J.M., Wang, L., Miles, M.F., Zhang, L., Dodd, P.R., Harris, R.A., 2000. Gene 1152 expression in human alcoholism: microarray analysis of frontal cortex. Alcohol.

1153 Clin. Exp. Res. 24, 1873-82.

1154 Li, L., Wu, Y., Wang, Y., Wu, J., Song, L., Xian, W., Yuan, S., Pei, L., Shang, Y., 
1155

1156

1157

1158

1159

1160

1161

1162

1163

1164

1165

1166

1167

1168

1169

1170

1171

1172

1173

1174

1175

1176

1177

1178

1179

1180

1181

1182

1183

2014. Resolvin D1 promotes the interleukin-4-induced alternative activation in BV-2 microglial cells. J. Neuroinflammation 11, 72. https://doi.org/10.1186/17422094-11-72

Liau, N.P.D., Laktyushin, A., Lucet, I.S., Murphy, J.M., Yao, S., Whitlock, E., Callaghan, K., Nicola, N.A., Kershaw, N.J., Babon, J.J., 2018. The molecular basis of JAK/STAT inhibition by SOCS1. Nat. Commun. 9, 1-14. https://doi.org/10.1038/s41467-018-04013-1

Lippai, D., Bala, S., Catalano, D., Kodys, K., Szabo, G., 2014. Micro-RNA-155 Deficiency Prevents Alcohol-Induced Serum Endotoxin Increase and Small Bowel Inflammation in Mice. Alcohol. Clin. Exp. Res. 38, 2217-2224. https://doi.org/10.1111/acer.12483

Lippai, D., Bala, S., Csak, T., Kurt-Jones, E.A., Szabo, G., 2013. Chronic AlcoholInduced microRNA-155 Contributes to Neuroinflammation in a TLR4-Dependent Manner in Mice. PLoS One 8, 1-10. https://doi.org/10.1371/journal.pone.0070945

Liput, D., Pauly, J., Stinchcomb, A., Nixon, K., 2017. Binge Alcohol Exposure Transiently Changes the Endocannabinoid System: A Potential Target to Prevent Alcohol-Induced Neurodegeneration. Brain Sci. 7, 158. https://doi.org/10.3390/brainsci7120158

Liput, D.J., Hammell, D.C., Stinchcomb, A.L., Nixon, K., 2013. Transdermal Delivery of Cannabidiol Attenuates Binge Alcohol-Induced Neurodegeneration in a Rodent Model of an Alcohol Use Disorder. Pharmacol Biochem Behav 111, 120-127. https://doi.org/10.1016/j.pbb.2013.08.013

Little, J., Villanueva, E., Klegeris, A., 2011. Therapeutic Potential of Cannabinoids in the Treatment of Neuroinflammation Associated with Parkinsons Disease. MiniReviews Med. Chem. 11, 582-590. https://doi.org/10.2174/138955711795906905

Liu, B., Song, S., Jones, P.M., Persaud, S.J., 2015. GPR55: From orphan to metabolic regulator? Pharmacol. Ther. 145, 35-42 https://doi.org/10.1016/j.pharmthera.2014.06.007

Long, J.Z., Li, W., Booker, L., Burston, J.J., Kinsey, S.G., Schlosburg, J.E., Pavón, F.J., 
1184

1185

1186

1187

1188

1189

1190

1191

1192

1193

1194

1195

1196

1197

1198

1199

1200

1201

1202

1203

1204

1205

1206

1207

1208

1209

1210

1211

1212

Serrano, A.M., Selley, D.E., Parsons, L.H., Lichtman, A.H., Cravatt, B.F., Chem, N., Author, B., 2009. Selective blockade of 2-arachidonoylglycerol hydrolysis produces cannabinoid behavioral effects. Nat Chem Biol 5, 37-44.

https://doi.org/10.1038/nchembio.129

Lou, Z.-Y., Yu, W.-B., Chen, J., Li, L., Jiang, L.-S., Xiao, B.-G., Liu, Z.-G., 2016. Neuroprotective Effect is Driven Through the Upregulation of CB1 Receptor in Experimental Autoimmune Encephalomyelitis. J. Mol. Neurosci. 58, 193-200. https://doi.org/10.1007/s12031-015-0656-9

Lowin, T., Straub, R.H., 2015. Cannabinoid-based drugs targeting CB1 and TRPV1, the sympathetic nervous system, and arthritis. Arthritis Res. Ther. https://doi.org/10.1186/s13075-015-0743-x

Lu, H.C., MacKie, K., 2016. An introduction to the endogenous cannabinoid system. Biol. Psychiatry 79, 516-525. https://doi.org/10.1016/j.biopsych.2015.07.028

Mandal, C., Halder, D., Jung, K.H., Chai, Y.G., 2018. Maternal alcohol consumption and altered miRNAs in the developing fetus: Context and future perspectives. J. Appl. Toxicol. 38, 100-107. https://doi.org/10.1002/jat.3504

Maroof, N., Pardon, M.C., Kendall, D.A., 2013. Endocannabinoid signalling in Alzheimer's disease. Biochemical Society Transactions. Portland Press. 15831587. https://doi.org/10.1042/BST20130140

Maroso, M., Balosso, S., Ravizza, T., Liu, J., Bianchi, M.E., Vezzani, A., 2011. Interleukin-1 type 1 receptor/Toll-like receptor signalling in epilepsy: The importance of IL-1beta and high-mobility group box 1. Journal of Internal Medicine. 319-326. https://doi.org/10.1111/j.1365-2796.2011.02431.x

Marrone, M.C., Morabito, A., Giustizieri, M., Chiurchiù, V., Leuti, A., Mattioli, M., Marinelli, Sara, Riganti, L., Lombardi, M., Murana, E., Totaro, A., Piomelli, D., Ragozzino, D., Oddi, S., Maccarrone, M., Verderio, C., Marinelli, Silvia, 2017. TRPV1 channels are critical brain inflammation detectors and neuropathic pain biomarkers in mice. Nat. Commun. 8. https://doi.org/10.1038/ncomms15292

Marsicano, G., 2003. CB1 Cannabinoid Receptors and On-Demand Defense Against 
1214 Matsuda, L.A., Lolait, S.J., Brownstein, M.J., Young, A.C., Bonner, T.I., 1990.

1215 Structure of a cannabinoid receptor and functional expression of the cloned cDNA.

$1216 \quad$ Nature 346, 561-564. https://doi.org/10.1038/346561a0

1217 McClain, J.A., Morris, S.A., Deeny, M.A., Marshall, S.A., Hayes, D.M., Kiser, Z.M.,

1218 Nixon, K., 2011. Adolescent binge alcohol exposure induces long-lasting partial

1219 activation of microglia. Brain. Behav. Immun. 25, S120-S128.

1220 https://doi.org/10.1016/j.bbi.2011.01.006

1221 McHugh, D., 2012. GPR18 in microglia: Implications for the CNS and

1222 endocannabinoid system signalling. Br. J. Pharmacol. 167, 1575-1582.

$1223 \quad$ https://doi.org/10.1111/j.1476-5381.2012.02019.x

1224 Mecha, M., Carrillo-Salinas, F.J., Feliú, A., Mestre, L., Guaza, C., 2016. Microglia activation states and cannabinoid system: Therapeutic implications. Pharmacol. Ther. 166, 40-55. https://doi.org/10.1016/j.pharmthera.2016.06.011

Melbourne, J.K., Thompson, K.R., Peng, H., Nixon, K., 2019. Its complicated: The relationship between alcohol and microglia in the search for novel pharmacotherapeutic targets for alcohol use disorders. Prog. Mol. Biol. Transl. Sci.

Moreno, S., Farioli-Vecchioli, S., Ceru`b, A.M.P., Ceru`b, C., 2004. 167, 179-221. https://doi.org/10.1016/BS.PMBTS.2019.06.011 Channels. Front. Mol. Neurosci. 11, 487. https://doi.org/10.3389/fnmol.2018.00487 peripheral receptor for cannabinoids. Nature 365, 61-65. 
Murray, P.J., 2007. The JAK-STAT Signaling Pathway: Input and Output Integration. J. Immunol. 178, 2623-2629. https://doi.org/10.4049/jimmunol.178.5.2623

Murray, P.J., 2006. STAT3-mediated anti-inflammatory signalling. Biochem. Soc. Trans. 34, 1028-1031. https://doi.org/10.1042/BST0341028

Nabavi, S.M., Ahmed, T., Nawaz, M., Devi, K.P., Balan, D.J., Pittalà, V., ArgüellesCastilla, S., Testai, L., Khan, H., Sureda, A., de Oliveira, M.R., Vacca, R.A., Xu, S., Yousefi, B., Curti, V., Daglia, M., Sobarzo-Sánchez, E., Filosa, R., Nabavi, S.F., Majidinia, M., Dehpour, A.R., Shirooie, S., 2019. Targeting STATs in neuroinflammation: The road less traveled! Pharmacol. Res. 141,73-84. https://doi.org/10.1016/j.phrs.2018.12.004

Nair, M.P., Figueroa, G., Casteleiro, G., Muñoz, K., Agudelo, M., 2015. Alcohol Versus Cannabinoids: A Review of Their Opposite Neuro-Immunomodulatory Effects and Future Therapeutic Potentials. J. Alcohol. drug Depend. 3. https://doi.org/10.4172/2329-6488.1000184

Nomura, D.K., Morrison, B.E., Blankman, J.L., Long, J.Z., Kinsey, S.G., Marcondes, M.C.G., Ward, A.M., Hahn, Y.K., Lichtman, A.H., Conti, B., Cravatt, B.F., 2011. Endocannabinoid hydrolysis generates brain prostaglandins that promote neuroinflammation. Science. 334, 809-813. https://doi.org/10.1126/science.1209200

O’Sullivan, S.E., 2016. An update on PPAR activation by cannabinoids. Br. J. Pharmacol. 173, 1899-1910. https://doi.org/10.1111/bph.13497

Okamoto, Y., Morishita, J., Tsuboi, K., Tonai, T., Ueda, N., 2004. Molecular characterization of a phospholipase $\mathrm{D}$ generating anandamide and its congeners. J. Biol. Chem. 279, 5298-305. https://doi.org/10.1074/jbc.M306642200

Orio, L., Alen, F., Pavón, F.J., Serrano, A., García-Bueno, B., 2019. Oleoylethanolamide, neuroinflammation, and alcohol abuse. Front. Mol. Neurosci. https://doi.org/10.3389/fnmol.2018.00490

Park, J.S., Svetkauskaite, D., He, Q., Kim, J.Y., Strassheim, D., Ishizaka, A., Abraham, E., 2004. Involvement of Toll-like Receptors 2 and 4 in Cellular Activation by 

https://doi.org/10.1074/jbc.M306793200

1272 Pascual, M., Blanco, A.M., Cauli, O., Miñarro, J., Guerri, C., 2007. Intermittent ethanol exposure induces inflammatory brain damage and causes long-term behavioural alterations in adolescent rats. Eur. J. Neurosci. 25, 541-550. https://doi.org/10.1111/j.1460-9568.2006.05298.x

Pascual, M., Montesinos, J., Guerri, C., 2018. Role of the innate immune system in the neuropathological consequences induced by adolescent binge drinking. J.

Pelição, R., Santos, M.C., Freitas-Lima, L.C., Meyrelles, S.S., Vasquez, E.C., Nakamura-Palacios, E.M., Rodrigues, L.C.M., 2016. URB597 inhibits oxidative stress induced by alcohol binging in the prefrontal cortex of adolescent rats.

Peñasco, S., Rico-Barrio, I., Puente, N., Fontaine, C.J., Ramos, A., Reguero, L., Gerrikagoitia, I., de Fonseca, F.R., Suarez, J., Barrondo, S., Aretxabala, X., García del Caño, G., Sallés, J., Elezgarai, I., Nahirney, P.C., Christie, B.R., Grandes, P., 2020. Intermittent ethanol exposure during adolescence impairs cannabinoid type 1

Perkins, A.E., Varlinskaya, E.I., Deak, T., 2019. From adolescence to late aging: A comprehensive review of social behavior, alcohol, and neuroinflammation across the lifespan. International Review of Neurobiology. Academic Press Inc. 148, 231Petrocellis, L., Di Marzo, V., 2016. The anti-inflammatory mediator palmitoylethanolamide enhances the levels of 2-arachidonoyl-glycerol and potentiates its actions at TRPV1 cation channels. Br. J. Pharmacol. 173, 11541162. https://doi.org/10.1111/bph.13084

1299 Pietr, M., Kozela, E., Levy, R., Rimmerman, N., Lin, Y.H., Stella, N., Vogel, Z., Juknat, 

A., 2009. Differential changes in GPR55 during microglial cell activation. FEBS Lett. 583, 2071-2076. https://doi.org/10.1016/j.febslet.2009.05.028

Qin, L., Crews, F.T., 2012. NADPH oxidase and reactive oxygen species contribute to alcohol-induced microglial activation and neurodegeneration. J. Neuroinflammation 9, 5. https://doi.org/10.1186/1742-2094-9-5

Qin, L., He, J., Hanes, R.N., Pluzarev, O., Hong, J.S., Crews, F.T., 2008. Increased systemic and brain cytokine production and neuroinflammation by endotoxin following ethanol treatment. J. Neuroinflammation 5. https://doi.org/10.1186/17422094-5-10

Rehm, J., Shield, K.D., 2019. Global Burden of Alcohol Use Disorders and Alcohol Liver Disease. Biomedicines 7, 99. https://doi.org/10.3390/biomedicines7040099

Ribeiro, R., Wen, J., Li, S., Zhang, Y., 2013. Involvement of ERK1/2, cPLA 2 and NF$\mathrm{kB}$ in microglia suppression by cannabinoid receptor agonists and antagonists. Prostaglandins Other Lipid Mediat. 100, 1-14. https://doi.org/10.1016/j.prostaglandins.2012.11.003

Rivera, P., Fernández-Arjona, M. del M., Silva-Peña, D., Blanco, E., Vargas, A., LópezÁvalos, M.D., Grondona, J.M., Serrano, A., Pavón, F.J., Rodríguez de Fonseca, F., Suárez, J., 2018. Pharmacological blockade of fatty acid amide hydrolase (FAAH) by URB597 improves memory and changes the phenotype of hippocampal microglia despite ethanol exposure. Biochem. Pharmacol. 157, 244-257. https://doi.org/10.1016/j.bcp.2018.08.005

Rivera, P., Silva-Peña, D., Blanco, E., Vargas, A., Arrabal, S., Serrano, A., Pavón, F.J., Bindila, L., Lutz, B., Rodríguez de Fonseca, F., Suárez, J., 2019. Oleoylethanolamide restores alcohol-induced inhibition of neuronal proliferation and microglial activity in striatum. Neuropharmacology 146, 184-197. https://doi.org/10.1016/j.neuropharm.2018.11.037

Robinson, R.H., Meissler, J.J., Fan, X., Yu, D., Adler, M.W., Eisenstein, T.K., 2015. A CB2-Selective Cannabinoid Suppresses T-Cell Activities and Increases Tregs and IL-10. J. Neuroimmune Pharmacol. 10, 318-332. https://doi.org/10.1007/s11481015-9611-3 
1330 Rodrigues, L.C.M.M., Gobira, P.H., de Oliveira, A.C., Pelicao, R., Teixeira, A.L., Moreira, F.A., Campos, A.C., Pelição, R., Teixeira, A.L., Moreira, F.A., Campos, A.C., 2014. Neuroinflammation as a possible link between cannabinoids and addiction. Acta Neuropsychiatr. 26, 334-346. https://doi.org/10.1017/neu.2014.24

1334

1335

1336

1337

1338

1339

1340

1341

1342

1343

1344

1345

1346

1347

1348

1349

1350

1351

1352

1353

1354

1355

1356

1357

1358

1359

Rojo, A.I., Pajares, M., García-Yagüe, A.J., Buendia, I., Van Leuven, F., Yamamoto, M., López, M.G., Cuadrado, A., 2018. Deficiency in the transcription factor NRF2 worsens inflammatory parameters in a mouse model with combined tauopathy and amyloidopathy. Redox Biol. 18, 173-180. https://doi.org/10.1016/j.redox.2018.07.006

Ryberg, E., Larsson, N., Sjögren, S., Hjorth, S., Hermansson, N.-O., Leonova, J., Elebring, T., Nilsson, K., Drmota, T., Greasley, P.J., 2007. The orphan receptor GPR55 is a novel cannabinoid receptor. Br. J. Pharmacol. 152, 1092-1101. https://doi.org/10.1038/sj.bjp.0707460

Saijo, K., Glass, C.K., 2011. Microglial cell origin and phenotypes in health and disease. Nat. Rev. Immunol. 11, 775-787. https://doi.org/10.1038/nri3086

Sanchez-Alavez, M., Nguyen, W., Mori, S., Wills, D.N., Otero, D., Ehlers, C.L., Conti, B., 2019. Time course of microglia activation and brain and blood cytokine/chemokine levels following chronic ethanol exposure and protracted withdrawal in rats. Alcohol 76, 37-45. https://doi.org/10.1016/j.alcohol.2018.07.005

Sanchez-Marin, L., Pavon, F.J., Decara, J., Suarez, J., Gavito, A., Castilla-Ortega, E., Rodriguez de Fonseca, F., Serrano, A., 2017. Effects of Intermittent Alcohol Exposure on Emotion and Cognition: A Potential Role for the Endogenous Cannabinoid System and Neuroinflammation. Front. Behav. Neurosci. 11, 15. https://doi.org/10.3389/fnbeh.2017.00015

Schlosburg, J.E., Blankman, J.L., Long, J.Z., Nomura, D.K., Pan, B., Kinsey, S.G., Nguyen, P.T., Ramesh, D., Booker, L., Burston, J.J., Thomas, E.A., Selley, D.E., Sim-Selley, L.J., Liu, Q., Lichtman, A.H., Cravatt, B.F., 2010. Chronic monoacylglycerol lipase blockade causes functional antagonism of the endocannabinoid system. Nat Neurosci 13, 1113-1119. 
1361 Sheng, W.S., Hu, S., Min, X., Cabral, G.A., Lokensgard, J.R., Peterson, P.K., 2005. Synthetic cannabinoid WIN55,212-2 inhibits generation of inflammatory mediators by IL-1B-stimulated human astrocytes. Glia 49, 211-219. https://doi.org/10.1002/glia.20108

Silva-Peña, D., Rivera, P., Alén, F., Vargas, A., Rubio, L., García-Marchena, N., Pavón, F.J., Serrano, A., Rodríguez de Fonseca, F., Suárez, J., 2019. Oleoylethanolamide Modulates BDNF-ERK Signaling and Neurogenesis in the Hippocampi of Rats Exposed to $\triangle 9$-THC and Ethanol Binge Drinking During Adolescence. Front. Mol. Neurosci. 12, 96. https://doi.org/10.3389/fnmol.2019.00096

Smith, S.R., Terminelli, C., Denhardt, G., 2000. Effects of cannabinoid receptor agonist and antagonist ligands on production of inflammatory cytokines and antiinflammatory interleukin-10 in endotoxemic mice. J. Pharmacol. Exp. Ther. 293, $136-150$.

Soethoudt, M., Grether, U., Fingerle, J., Grim, T.W., Fezza, F., De Petrocellis, L., Ullmer, C., Rothenhäusler, B., Perret, C., Van Gils, N., Finlay, D., Macdonald, C., Chicca, A., Gens, M.D., Stuart, J., De Vries, H., Mastrangelo, N., Xia, L., Alachouzos, G., Baggelaar, M.P., Martella, A., Mock, E.D., Deng, H., Heitman, L.H., Connor, M., Marzo, V. Di, Gertsch, J., Lichtman, A.H., Maccarrone, M., Glass, M., Van Der Stelt, M., 2017. Cannabinoid CB 2 receptor ligand profiling reveals biased signalling and off-target activity. Nat. Commun. https://doi.org/10.1038/ncomms13958

Stella, N., 2010. Cannabinoid and cannabinoid-like receptors in microglia, astrocytes, and astrocytomas. Glia 58, 1017-1030. https://doi.org/10.1002/glia.20983

Vallée, A., Lecarpentier, Y., Guillevin, R., Vallée, J.-N., 2017. Effects of cannabidiol interactions with $\mathrm{Wnt} / \beta$-catenin pathway and PPAR $\gamma$ on oxidative stress and neuroinflammation in Alzheimer's disease. Acta Biochim. Biophys. Sin. (Shanghai). 49, 853-866. https://doi.org/10.1093/abbs/gmx073

Vallés, S.L., Blanco, A.M., Pascual, M., Guerri, C., 2004. Chronic ethanol treatment enhances inflammatory mediators and cell death in the brain and in astrocytes. 
1391 Varga, T., Czimmerer, Z., Nagy, L., 2011a. PPARs are a unique set of fatty acid

1392

1393

1394

1395

1396

1397

1398

1399

1400

1401

1402

1403

1404

1405

1406

1407

1408

1409

1410

1411

1412

1413

1414

1415

1416

1417

1418 regulated transcription factors controlling both lipid metabolism and inflammation. Biochim. Biophys. Acta - Mol. Basis Dis. 1812, 1007-1022. https://doi.org/10.1016/J.BBADIS.2011.02.014

Varga, T., Czimmerer, Z., Nagy, L., 2011b. PPARs are a unique set of fatty acid regulated transcription factors controlling both lipid metabolism and inflammation. Biochim. Biophys. Acta - Mol. Basis Dis. 1812, 1007-1022. https://doi.org/10.1016/J.BBADIS.2011.02.014

Walter, L., Franklin, A., Witting, A., Wade, C., Xie, Y., Kunos, G., Mackie, K., Stella, N., 2003. Nonpsychotropic Cannabinoid Receptors Regulate Microglial Cell Migration.

Wang, D., Shi, L., Xin, W., Xu, Jiancheng, Xu, Jing, Li, Q., Xu, Z., Wang, J., Wang, G., Yao, W., He, B., Yang, Y., Hu, M., 2017. Activation of PPAR $\gamma$ inhibits proinflammatory cytokines production by upregulation of miR-124 in vitro and in vivo. Biochem. Biophys. Res. Commun. 486, 726-731. https://doi.org/10.1016/j.bbrc.2017.03.106

Wang, Z., Yang, Y., Yang, H., Capó-Aponte, J.E., Tachado, S.D., Wolosin, J.M., Reinach, P.S., 2011. NF- $\mathrm{BB}$ feedback control of JNK1 activation modulates TRPV1-induced increases in IL-6 and IL- 8 release by human corneal epithelial cells. Mol. Vis. 17, 3137-46.

Wen, J., Ribeiro, R., Tanaka, M., Zhang, Y., 2015. Activation of CB2 receptor is required for the therapeutic effect of ABHD6 inhibition in experimental autoimmune encephalomyelitis. Neuropharmacology 99, 196-209. https://doi.org/10.1016/j.neuropharm.2015.07.010

World Health Organization, W., 2018. Global status report on alcohol and health 2018. World Health Organization.

Yamanaka, M., Ishikawa, T., Griep, A., Axt, D., Kummer, M.P., Heneka, M.T., 2012. PPAR $\gamma /$ RXRA-induced and CD36-mediated microglial amyloid- $\beta$ phagocytosis 

results in cognitive improvement in amyloid precursor protein/presenilin 1 mice. J. Neurosci. 32, 17321-17331. https://doi.org/10.1523/JNEUROSCI.1569-12.2012

Yang, L., Guo, H., Li, Y., Meng, X., Yan, L., Dan Zhang, Wu, S., Zhou, H., Peng, L., Xie, Q., Jin, X., 2016. Oleoylethanolamide exerts anti-inflammatory effects on LPS-induced THP-1 cells by enhancing PPAR $\alpha$ signaling and inhibiting the NF- $\kappa \mathrm{B}$ and ERK1/2/AP-1/STAT3 pathways. Sci. Rep. 6, 34611. https://doi.org/10.1038/srep34611

Yang, Y., Yang, H., Wang, Z., Varadaraj, K., Kumari, S.S., Mergler, S., Okada, Y., Saika, S., Kingsley, P.J., Marnett, L.J., Reinach, P.S., Edu, P., 2013. Cannabinoid receptor 1 suppresses transient receptor potential vanilloid 1-induced inflammatory responses to corneal injury. Cell Signal 25, 501-511. https://doi.org/10.1016/j.cellsig.2012.10.015

Yuan, M., Kiertscher, S.M., Cheng, Q., Zoumalan, R., Tashkin, D.P., Roth, M.D., 2002. $\Delta 9$-Tetrahydrocannabinol regulates Th1/Th2 cytokine balance in activated human T cells. J. Neuroimmunol. 133, 124-131. https://doi.org/10.1016/S01655728(02)00370-3

Zarruk, J.G., Fernández-López, D., García-Yébenes, I., García-Gutiérrez, M.S., Vivancos, J., Nombela, F., Torres, M., Burguete, M.C., Manzanares, J., Lizasoain, I., Moro, M.A., 2012. Cannabinoid type 2 receptor activation downregulates stroke-induced classic and alternative brain macrophage/microglial activation concomitant to neuroprotection. Stroke 43, 211-9. https://doi.org/10.1161/STROKEAHA.111.631044

Zhang, M., An, C., Gao, Y., Leak, R.K., Chen, J., Zhang, F., 2013. Emerging roles of Nrf2 and phase II antioxidant enzymes in neuroprotection. Prog. Neurobiol.100, 30-47. https://doi.org/10.1016/j.pneurobio.2012.09.003

Zhao, X., Sun, G., Ting, S.M., Song, S., Zhang, J., Edwards, N.J., Aronowski, J., 2015. Cleaning up after ICH: The role of Nrf2 in modulating microglia function and hematoma clearance. J. Neurochem. 133, 144-152. https://doi.org/10.1111/jnc.12974

Zhou, Y., Huang, T., Lee, F., Kreek, M.J., 2016. Involvement of Endocannabinoids in 
Alcohol "Binge" Drinking: Studies of Mice with Human Fatty Acid Amide Hydrolase Genetic Variation and After CB1 Receptor Antagonists. Alcohol. Clin. Exp. Res. 40, 467-473. https://doi.org/10.1111/acer.12989

Zhou, Y., Schwartz, B.I., Giza, J., Gross, S.S., Lee, F.S., Kreek, M.J., 2017. Blockade of alcohol escalation and "relapse" drinking by pharmacological FAAH inhibition in male and female C57BL/6J mice. Psychopharmacology (Berl). 234, 2955-2970. https://doi.org/10.1007/s00213-017-4691-9

1456 Zou, J.Y., Crews, F.T., 2005. TNF $\alpha$ potentiates glutamate neurotoxicity by inhibiting glutamate uptake in organotypic brain slice cultures: Neuroprotection by NFkB inhibition. Brain Res. 1034, 11-24. https://doi.org/10.1016/j.brainres.2004.11.014 